\title{
$N$-Acetylaspartate Synthase Deficiency Corrects the Myelin Phenotype in a Canavan Disease Mouse Model But Does Not Affect Survival Time
}

\author{
Helena Maier, ${ }^{1}$ Lihua Wang-Eckhardt, ${ }^{1}$ Dieter Hartmann, ${ }^{2}$ Volkmar Gieselmann, ${ }^{1,3}$ and Matthias Eckhardt ${ }^{1,3}$ \\ ${ }^{1}$ Institute of Biochemistry and Molecular Biology and ${ }^{2}$ Institute of Anatomy, University of Bonn, 53115 Bonn, Germany, and ${ }^{3}$ Center for Rare Diseases, \\ 53105 Bonn, Germany
}

Canavan disease (CD) is a severe, lethal leukodystrophy caused by deficiency in aspartoacylase (ASPA), which hydrolyzes $\mathrm{N}$-acetylaspartate (NAA). In the brains of CD patients, NAA accumulates to high millimolar concentrations. The pathology of the disease is characterized by loss of oligodendrocytes and spongy myelin degeneration in the CNS. Whether accumulating NAA, absence of NAA-derived acetate, or absence of any unknown functions of the ASPA enzyme is responsible for the pathology of the disease is not fully understood. We generated ASPA-deficient $\left(\mathrm{Aspa}^{\text {nur7/nur7 }}\right)$ mice that are also deficient for NAA synthase Nat8L $\left(\mathrm{Nat} \mathrm{L}^{-/-} / \mathrm{Aspa}^{\text {nur7/nur7 }}\right)$. These mice have no detectable NAA. Nevertheless, they exhibited normal myelin content, myelin sphingolipid composition, and full reversal of spongy myelin and axonal degeneration. Surprisingly, although pathology was fully reversed, the survival time of the mice was not prolonged. In contrast, Aspa ${ }^{\text {nur7/nur7 }}$ mice with only one intact Nat8L allele accumulated less NAA, developed a less severe pathology, phenotypic improvements, and, importantly, an almost normal survival time. Therefore, inhibition of NAA synthase is a promising therapeutic option for $\mathrm{CD}$. The reduced survival rate of $\mathrm{Nat} \mathrm{L}^{-1-} / \mathrm{Aspa}^{\text {nur7/nur7 }}$ mice, however, indicates that complete inhibition of $\mathrm{NAA}$ synthase may bear unforeseeable risks for the patient. Furthermore, we demonstrate that acetate derived from NAA is not essential for myelin lipid synthesis and that loss of NAA-derived acetate does not cause the myelin phenotype of Aspa ${ }^{\text {nur7/nur7 }}$ mice. Our data clearly support the hypothesis that NAA accumulation is the major factor in the development of CD.

Key words: aspartoacylase; Canavan disease; leukodystrophy; $N$-acetylaspartate; NAA synthase; spongy degeneration

Significance Statement

Canavan disease (CD) is a severe, lethal leukodystrophy caused by aspartoacylase deficiency leading to accumulation of its substrate, $N$-acetylaspartate (NAA), and spongy myelin degeneration. In our study, we found that deletion of the NAA synthase gene Nat8L in a CD mouse model prevents myelin degeneration. This shows that accumulation of NAA to toxic levels causes the spongy myelin degeneration and excludes that a deficiency of NAA degradation products is responsible for the disease. This conclusion also suggests that inhibition of NAA synthase may be a therapeutic option for CD. The observed sudden premature death of Nat8L-deficient mice, however, also indicates that complete inhibition of NAA synthase may bear unforeseeable risks for patients.

\section{Introduction}

$\mathrm{N}$-acetylaspartate (NAA) is an abundant amino acid derivative in the nervous system of vertebrates (for review, see Baslow, 2003; Moffett et al., 2007). NAA is synthesized by an NAA synthase, encoded by the Nat8L gene, which is mainly expressed in neurons (Wiame et al., 2009). NAA is released from neurons by an un-

\footnotetext{
Received March 18, 2015; revised Sept. 14, 2015; accepted Sept. 20, 2015.

Author contributions: M.E. designed research; H.M., L.W.-E., D.H., and M.E. performed research; H.M., L.W.-E., D.H., V.G., and M.E. analyzed data; H.M., D.H., V.G., and M.E. wrote the paper.

This work was supported by the Deutsche Forschungsgemeinschaft (M.E.). V.G. is a member of the Bonn Cluster of Excellence ImmunoSensation. We thank Arthur Butt for kindly providing L-MAG antibodies.

The authors declare no competing financial interests.
}

known mechanism. Degradation of NAA takes place in oligodendrocytes, which express the NAA hydrolase aspartoacylase (ASPA), and possibly to some extent also in other cell types (Moffett et al., 2011). In addition, neuronal NAA is a precursor for the neuropeptides $N$-acetylaspartylglutamate (NAAG) and $\mathrm{N}$-acetylaspartylglutamylglutamate, which are synthesized by two related peptide synthases (Becker et al., 2010; Collard et al., 2010; Lodder-Gadaczek et al., 2011). Apart from its role as a

Correspondence shoud be addressed to Matthias Eckhardt, Institute of Biochemistry and Molecular Biology, University of Bonn, Nussallee 11, 53115 Bonn, Germany. E-mail: eckhardt@uni-bonn.de. DOI:10.1523/JNEUROSCI.1056-15.2015

Copyright $\odot 2015$ the authors $\quad 0270-6474 / 15 / 3514501-16 \$ 15.00 / 0$ 
substrate for these synthases, the physiological role of NAA is largely unclear. NAA may be an acetyl-group carrier to supply oligodendrocytes with substrates for myelin lipid synthesis (Madhavarao et al., 2005) and may function as a molecular water pump to reduce osmotic stress in neurons (Baslow et al., 2013).

ASPA deficiency causes a rare leukodystrophy, Canavan disease (CD), in which NAA accumulates to high millimolar concentrations (Matalon et al., 1988). Two main, non-mutually exclusive hypotheses may explain the pathology of $\mathrm{CD}$. According to the first, the NAA hydrolysis product acetate is required for myelin lipid synthesis and loss of ASPA causes a reduction in acetyl group supply for lipid synthesis (Namboodiri et al., 2006). The second model assumes that, because of its large hydrate shell, high NAA concentration causes "osmotic stress" to myelin/oligodendrocytes and this causes loss of myelin (Baslow et al., 2013). The latter hypothesis is supported by the severe vacuolation in $\mathrm{CD}$. An argument against this hypothesis, however, was the observation that restoration of ASPA expression in neurons did not improve the myelin phenotype in a CD mouse model (Klugmann et al., 2005). Furthermore, acetyl groups derived from NAA may also be used for acetylation reactions (e.g., protein acetylation) and ASPA could have other, currently unknown functions, the loss of which could cause oligodendrocyte death; however, there are currently no experimental data to support this hypothesis.

To further elucidate the cause of myelin loss in CD, we examined the effect of an NAA synthase deficiency in the Aspa ${ }^{\text {nur7/nur7 }}$ mouse mutant, an established CD mouse model showing widespread spongiform degeneration in the CNS (Traka et al., 2008). Nat8 $\mathrm{L}^{-1-}$ mice that did not lack ASPA, did not show any signs of a myelin phenotype, and exhibited normal myelin protein and lipid levels throughout development. Moreover, our data show clearly that the myelin pathology of Aspa ${ }^{\text {nur } 7 / n u r 7}$ mice can be rescued by the additional knock-out of the NAA-synthase Nat8L. Most surprisingly, however, the impressive reversal of myelin pathology did not result in prolonged survival times. In contrast, the survival rate of Aspa ${ }^{\text {nur7/nur7 }}$ mice heterozygous for Nat8L was almost normal until 1 year of age. This correlated with some behavioral improvements and a less severe spongy degeneration. Our results show that accumulation of NAA to toxic levels is the key event in the development of CD and the absence of NAA degradation products is not responsible for myelin degeneration in Aspa ${ }^{\text {nur } 7 / n u r 7}$ mice. Our findings suggest that partial inhibition of NAA-synthase may be a therapeutic option for CD.

\section{Materials and Methods}

Mouse lines. Mice were housed on a regular dark/light cycle (12 h dark from 6:00 P.M. to 6:00 A.M. and $12 \mathrm{~h}$ light from 6:00 A.M. to 6:00 P.M.).

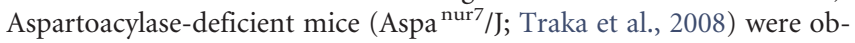
tained from The Jackson Laboratory. Although this mouse line has been reported to have a pure C57BL/6 genetic background, a single nucleotide polymorphism panel analysis done at The Jackson Laboratory showed that 7 of 27 markers were not of the C57BL/6 allele type (The Jackson Laboratory; http://jaxmice.jax.org/strain/008607.html). Nat8L-deficient mice were generated as follows. A Nat8L targeting construct containing floxed exon 3 of the Nat8L gene and a loxP/FRT-flanked neomycin resistance gene followed by an IRES-lacZ cassette was generated by the recombineering technique using a $129 / \mathrm{Sv}$ BAC clone (Source BioScience). The linearized targeting construct was electroporated into HM-1 embryonic stem cells (Magin et al., 1992) and subjected to selection with G418 using standard methods (Hogan et al., 1994). G418resistant colonies were tested for homologous recombination by PCR and positive clones were confirmed by Southern blotting using $5^{\prime}$ - and 3 '-external probes. One selected positive ES cell clone was used to produce chimeric male founder mice that were bred with $\mathrm{C} 57 \mathrm{BL} / 6$ females. Floxed heterozygous mice were mated with pgk-Cre mice to delete exon 3 and the neomycin selection cassette. Heterozygous mice were than mated to obtain Nat8 $\mathrm{L}^{-1-}$ mice. Mice of the established Nat8 $\mathrm{L}^{-1-}$ line were crossed with $\mathrm{Aspa}^{\text {nur7/+ }}$ mice. Most of the animals analyzed in this study were obtained from Nat8 $\mathrm{L}^{+/-}$, Aspa $^{\text {nur7/nur7 }} \times \mathrm{Nat}^{\text {n }} \mathrm{L}^{+/-} / \mathrm{Aspa}^{\text {nur7/nur7 }}$ breeding pairs. Mice with the genotypes Nat8 $\mathrm{L}^{+/+} / \mathrm{Aspa}^{+/+}$and $\mathrm{Nat} 8 \mathrm{~L}^{+/+} / \mathrm{Aspa}^{\text {nur7/+ }}$ were used as controls in all experiments, if not otherwise indicated. All animal experiments were performed in compliance with German national guidelines and approved by the Landesamt für Natur, Umwelt und Verbraucherschutz NRW (Düsseldorf, Germany).

Genotyping. Genotyping of the Nat8L gene was done by PCR using the following primers: 5' -TCCCTGTGTCCCATGCCCGT-3', 5' - TCCCA GCCCTTGGTCTGCCA-3', and 5'-TGGGGCAAGTGTGGAGGGTGG-3' (PCR products: wild-type allele $=225 \mathrm{bp}$, knock-out allele $=266 \mathrm{bp}$, floxed allele $=316 \mathrm{bp}$ ). Genotyping of the Aspa gene was done by PCR followed by restriction digest analysis. PCR was done using the two primers 5' -TAAAATCAAGAGCATGTTTTATCATTTTTCTCATCT-3' and $5^{\prime}$-CTCCTGTCGCAACCTATTTCTTG-3'. The first primer anneals directly upstream of the nur7 mutation and has a mismatch at the second to last position ( $\mathrm{T}$ to $\mathrm{C}$ transition). In the presence of the nur7 mutation, a BfaI restriction site (CTAG) is formed in the PCR product. The PCR product was digested with $\mathrm{BfaI}$ and analyzed by agarose gel electrophoresis. Digested PCR products gave fragments of 170,161 , and $51 \mathrm{bp}$ in the wild-type allele and fragments of $161,133,51$, and 37 bp in the nur7 allele.

Antibodies. The following primary antibodies were used for Western blotting (WB), immunofluorescence (IF), and immunohistochemistry (IHC): mouse anti- $\beta / \mathrm{A} 4$ amyloid precursor protein (APP) clone $22 \mathrm{C} 11$ (IHC 1:250, MAB348; Merck/Millipore), mouse anti-glial fibrillary acidic protein (GFAP) (WB 1:1000, IF 1:100, ICN691102; MP Biomedicals), rabbit anti-myelin basic protein (MBP) (WB 1:5000, AB980; Merck/Millipore), mouse anti-2'3'-cyclic nucleotide 3 '-phosphohydrolase (CNPase) clone 11-5B (WB 1:1000, MAB326; Merck/Millipore), mouse anti-proteolipid protein (PLP) (WB 1:1000, MAB388; Merck/Millipore), and mouse anti- $\alpha$-tubulin (WB 1:5000, T5168; Sigma-Aldrich). The rabbit anti-large myelin associated glycoprotein (L-MAG) antiserum (WB 1:5000) was kindly provided by Dr. Arthur Butt (Center for Neuroscience Research, King's College London). The following secondary antibodies were used: goat anti-mouse Alexa Fluor 546 (IF 1:400, A-11030; Thermo Scientific), goat anti-rabbit Alexa Fluor 546 (IF 1:400, A-11035; Thermo Scientific), goat anti-rabbit IgG DyLight 800 (WB 1:10,000, 35571; Thermo Scientific), goat anti-rabbit IgG DyLight 649 (WB 10,000, 35565; Thermo Scientific), goat anti-mouse IgG DyLight 800 (WB 10,000, 35521; Thermo Scientific), and goat antimouse IgG DyLight 649 (WB 10,000, 35515; Thermo Scientific).

Northern blot analysis. Total RNA of murine brain was isolated using TRIzol (Thermo Scientific) as described by the manufacturer. Total RNA (20 $\mu \mathrm{g} /$ lane) was separated in a $1 \mathrm{~m}$ formaldehyde/1\% agarose gel and transferred onto Hybond- $\mathrm{N}^{+}$nylon membrane (GE Healthcare). A 564 bp fragment of the Nat8L cDNA was used to synthesize a digoxigeninlabeled RNA antisense probe with DIG RNA labeling Mix (Roche). Hybridization was performed using standard procedures. Antidigoxigenin-AP Fab fragments (11093274910; Roche) were used for signal detection and bound antibody was visualized by enhanced chemiluminescence with disodium 3-(4-methoxyspiro\{1,2-dioxetane-3,2' (5'-chloro)tricyclo[3.3.1.13,7] decan $\}$-4-yl)phenylphosphate (Roche) as a substrate after exposure to $\mathrm{x}$-ray films.

Reverse transcription real-time PCR. Total RNA was isolated using TRIzol (Life Technologies) following the instructions of the manufacturer. cDNA was synthesized out of $5 \mu \mathrm{g}$ of RNA using Superscript II reverse transcriptase (GE Healthcare) as described previously (Becker et al., 2008). Real-time PCR was done using SYBR Select Master Mix (Life Technologies) in an Applied Biosystems 7300 Real Time PCR system (Life Technologies). Data were analyzed by the $2^{-\mathrm{dCt}}$ method using actin as a housekeeping gene. All PCRs were done in duplicate and at least three independent experiments using RNA preparations from three mice per genotype were performed. Data were tested for significance using a twotailed $t$ test with a significance level of $p<0.05$. The following primer 
A
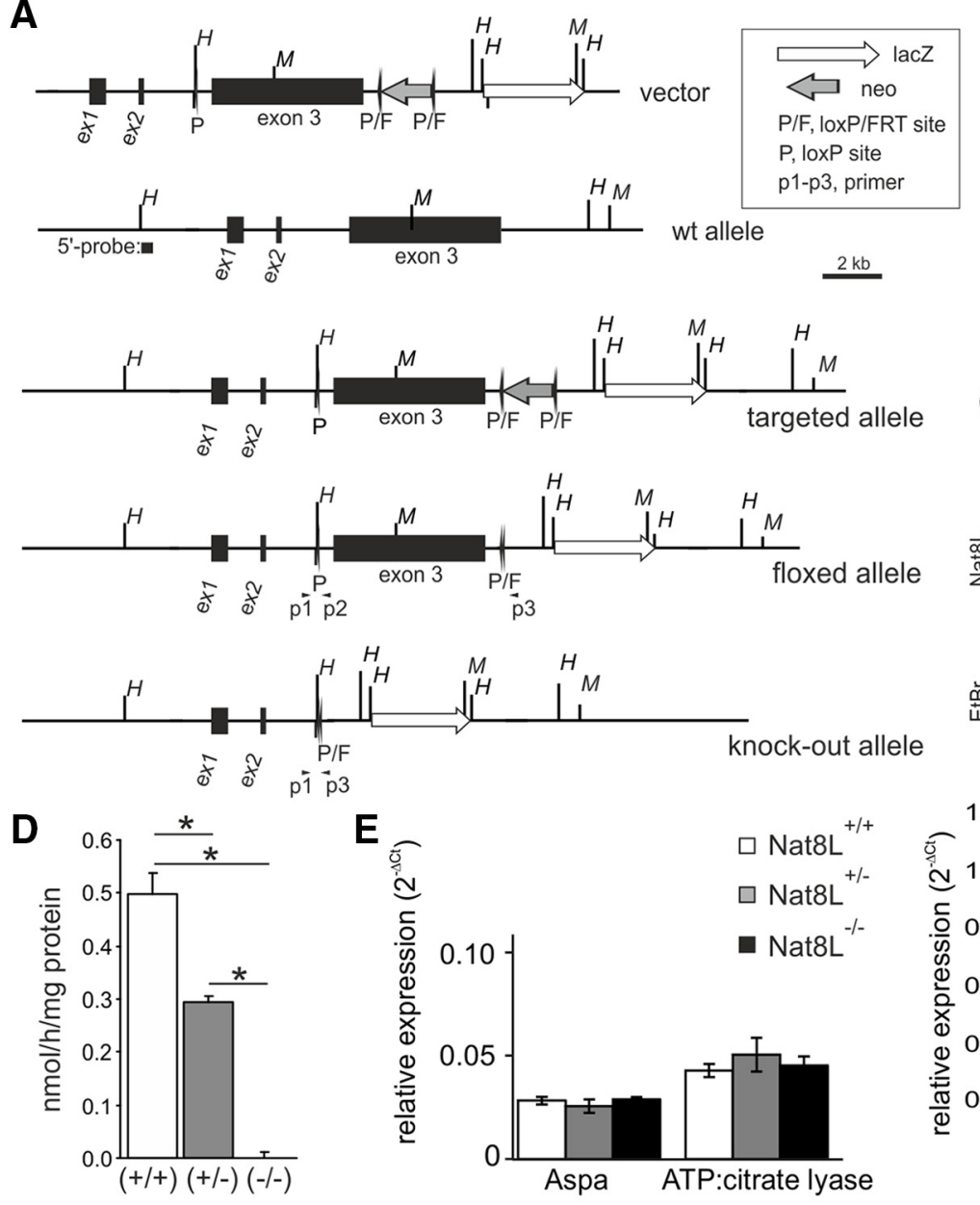

$\mathbf{F}$

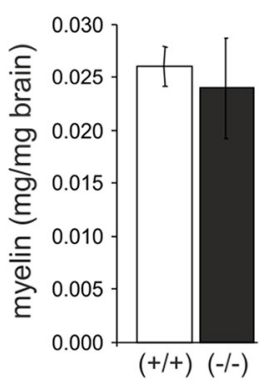

$\mathbf{E}$

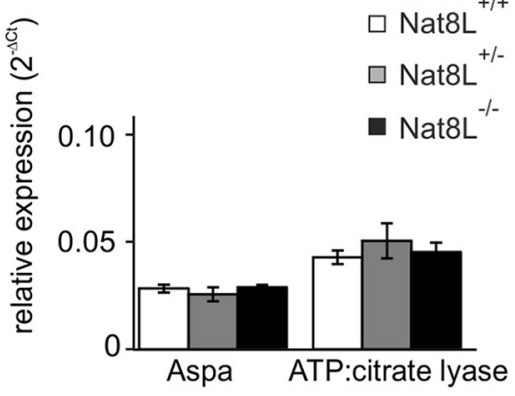

G

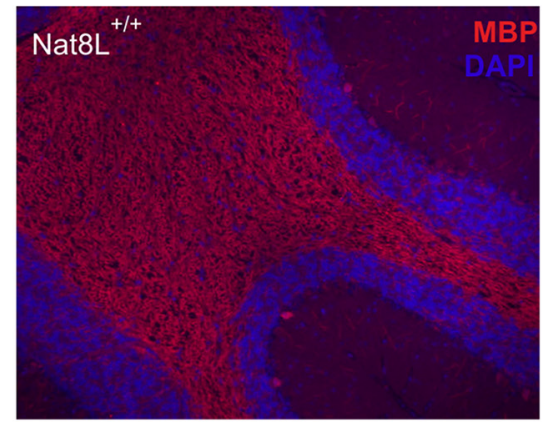

B

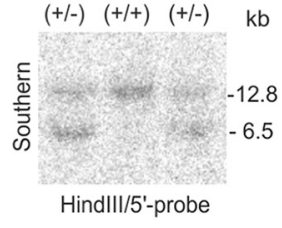

$(+/+) \quad(+/-) \quad(-/-)(\mathrm{fl} /+) \quad$ bp

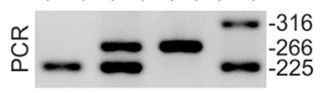

C

P11 P20

$(-/-)(+/-)(+/+) \quad(-/-)(+/-)(+/+)$
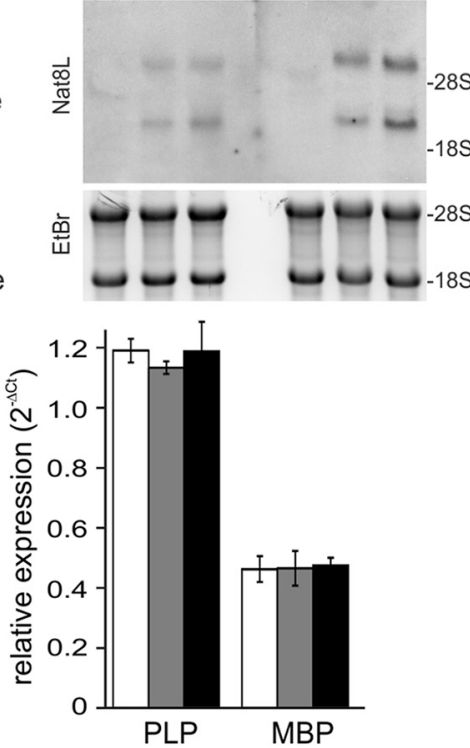

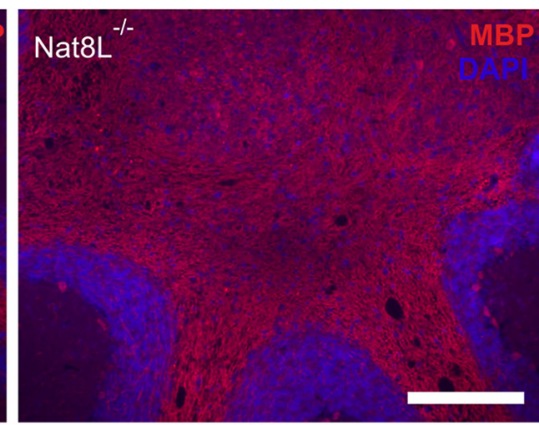

Figure 1. Generation and characterization of Nat8L-deficient mice. $\boldsymbol{A}$, Targeting strategy to generate a conditional, floxed Nat8L allele. An FRT-flanked neomycin resistance gene and a lacZ reporter gene with an upstream splice acceptor site and an internal ribosome entry site (IRES) were inserted downstream of exon 3. Mice containing the targeted floxed Nat8L allele were crossed with transgenic deleter-Flp mice to remove the neomycin selection cassette or with pgk-Cre transgenic mice to create a Nat8L knock-out allele expressing the lacZ reporter gene under the control of the Nat8L promoter. The position of restriction enzyme cut sites used for Southern blot analysis ( $\mathrm{H}$, Hindlll; $\mathrm{M}, \mathrm{Mfel}$ ) and the position of primers (p1-p3) used for PCR are indicated. $\boldsymbol{B}$, Southern blot analysis of mouse genomic DNA digested with Hindlll of wild-type $(+/+)$ and heterozygous $(+/-)$ Nat8L mice. PCR analysis of genomic DNA from Nat8L ${ }^{+/+}$, Nat8L ${ }^{+/-}$, Nat8L ${ }^{-/-}$, and heterozygous floxed ( $\mathrm{fl} /+$ ) mice: wild-type allele $=225 \mathrm{bp}$; knock-out allele $=266 \mathrm{bp}$; floxed allele $=316 \mathrm{bp}$ (position of PCR primers are shown in $A$ ). $C$, Northern blot analysis of Nat8L expression in brain of 11- and 20-d-old Nat8L ${ }^{-/-}$, Nat8L $\mathrm{L}^{+/-}$, and Nat8L ${ }^{+/+}$littermates indicating the absence and reduced expression of Nat8L mRNA in Nat8L $\mathrm{L}^{-1-}$ and Nat8L ${ }^{+/-}$mice, respectively, and upregulation of Nat8 $\mathrm{L}$ during postnatal development in wild-type mice. Two different mRNAs are present because of an alternative polyadenylation site in exon 3 . D, NAA synthase activity was

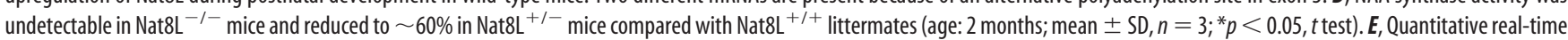
PCR revealed no significant changes in the expression of Aspa, ATP:citrate lyase, PLP, and MBP in total brain of 20-d-old Nat8L ${ }^{-/-}$, Nat8L $^{+/-}$and wild-type littermates (mean \pm SEM, $n=3$ ). $\boldsymbol{F}$, Myelin was isolated from the brains of 2-month-old Nat8 $\mathrm{L}^{+/+}$and Nat8 $\mathrm{L}^{-/-}$mice by sucrose gradient centrifugation. No significant difference in myelin content was observed (mean \pm SD, $n=$ 3). G, MBP immunofluorescence staining on brain paraffin sections of 1-year-old animals showed no obvious difference between wild-type and Nat8L ${ }^{-1-}$ mice in cerebellum (G) or other brain regions (data not shown). Scale bar, $200 \mu \mathrm{m}$.

(TGTGCGCTGCACACGGACAT, TTGCCGTCCAGCACAGCCAC), and PLP (TGAGCGCAACGGTAACAGG, GGGAGAACACCATACATTC TGG).

Measurement of NAA and NAAG. NAA and NAAG were determined by an LC/MS method described previously (Lodder-Gadaczek et al., 
A

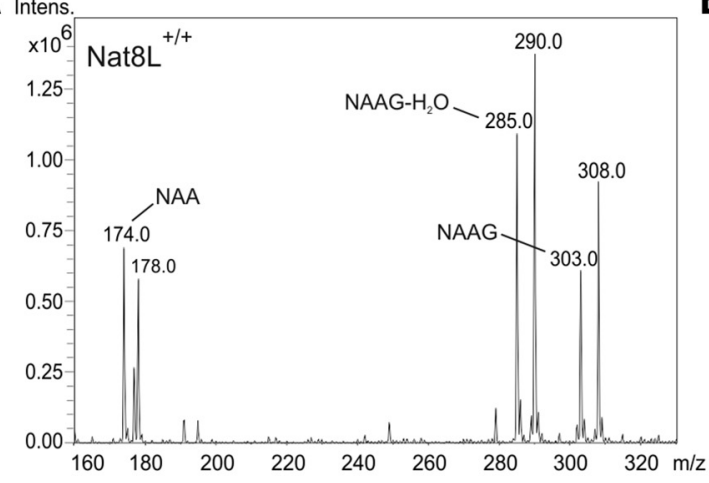

C

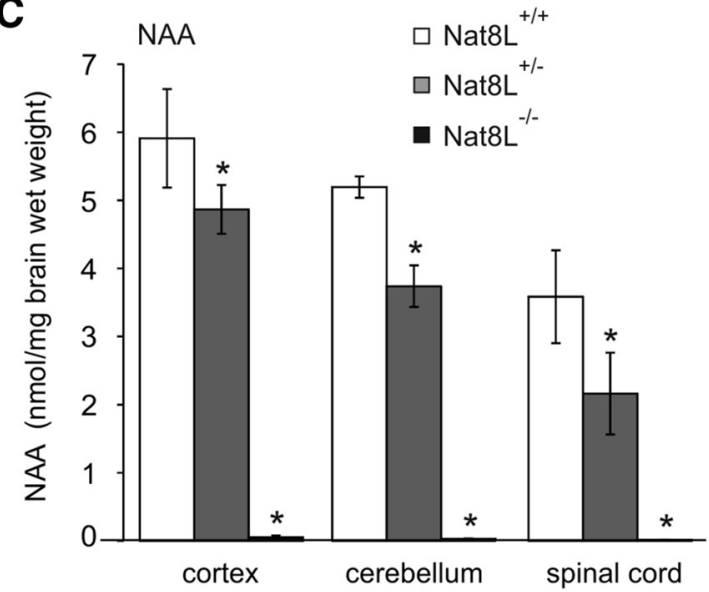

$\mathbf{E}$

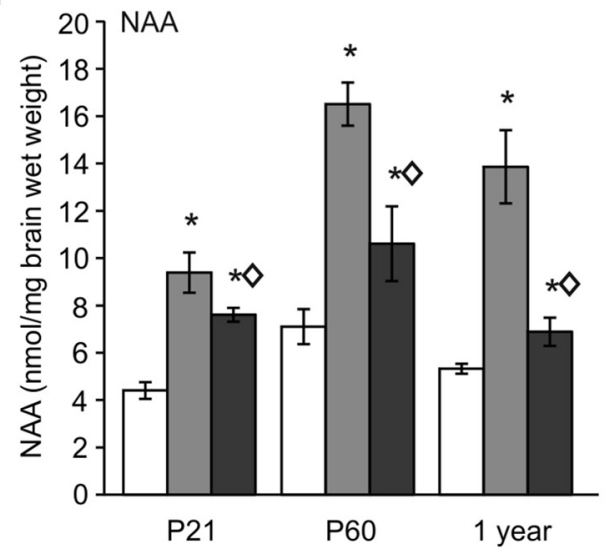

B Intens

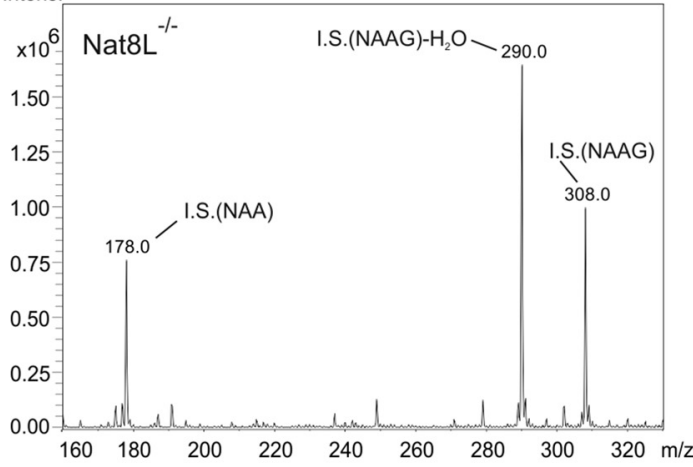

D

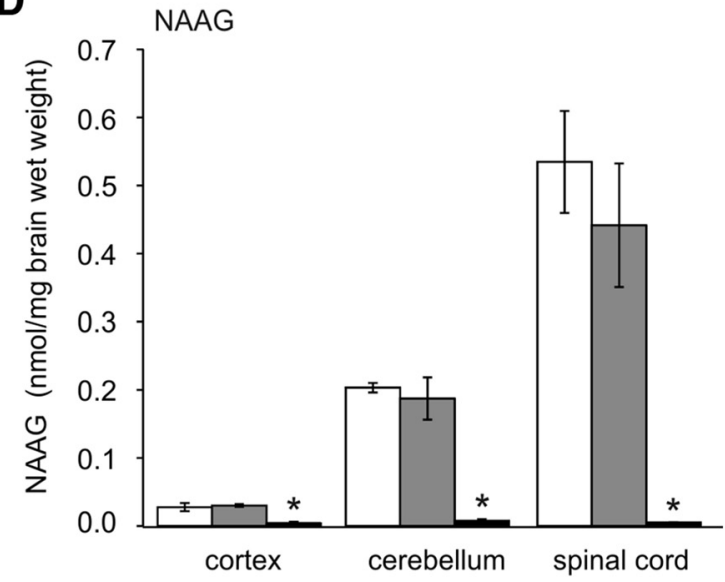

$\mathbf{F}$

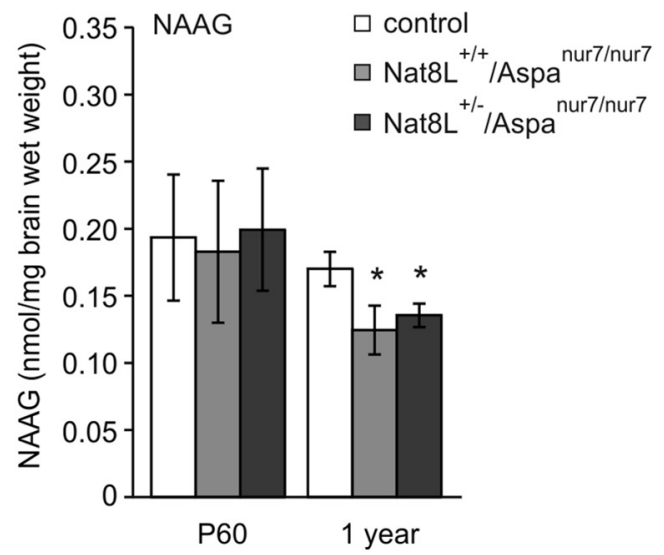

Figure 2. NAA and NAAG quantification. Quantification of NAA and NAAG was done by mass spectrometry using stable-isotope-labeled internal standards. Representative ESI-MS spectra (negative ion mode) of methanolic peptide extracts of the cerebellum from 3-month-old Nat8 $\mathrm{L}^{+/+}(\boldsymbol{A})$ and Nat8 $\mathrm{L}^{-/-}(\boldsymbol{B})$ mice are shown. Mass peaks of $m / z 303.0$ and 174.0 correspond to NAAG and NAA, respectively. As expected, none of these signals was detectable in the peptide extracts of Nat8 $\mathrm{L}^{-1-}$ mice $(\boldsymbol{B})$. Mass peaks of $m / z 308.0$ and 178.0 correspond to the ${ }^{13} \mathrm{C}-$ labeled $N A A G$ and NAA internal standards (I.S.) that were used for quantification. Mass peaks of $m / z 285.0$ and 290.0 correspond to NAAG and ${ }^{13} \mathrm{C}-\mathrm{NAAG}$ after elimination of $\mathrm{H}_{2} \mathrm{O}$, respectively. $\boldsymbol{C}, \boldsymbol{D}$, ESI-MS detection of NAA and NAAG in selected brain regions of 3-month-old mice. C, Compared with wild-type (Nat8 $\mathrm{L}^{+/+}$) littermates, Nat8 $\mathrm{L}^{+/-}$mice showed a significant reduction in NAA in cortex, cerebellum, and spinal cord (1-tailed $t$ test, ${ }^{*} p<0.05, n=3$ ), whereas NAA was undetectable in Nat8L ${ }^{-1-}$ mice. $D$, The concentration of NAAG was significantly reduced below the detection limit in all three examined brain regions in Nat8L $\mathrm{L}^{-1-}$ mice, but was not significantly altered in Nat8 $\mathrm{L}^{+/-}$mice compared with wild-type controls. $\boldsymbol{E}, \boldsymbol{F}, \mathrm{Quantification}$ of NAA and NAAG in total brain homogenates.

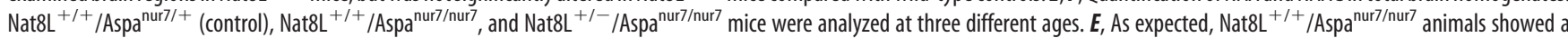
statistically significant increase of NAA compared with Nat8L ${ }^{+/+} / \mathrm{Aspa}^{\text {nur7/+}}$ littermates (control) at every examined time point $\left(t\right.$ test, $\left.{ }^{*} p<0.05, n=3-6\right)$. Likewise, NAA was elevated in

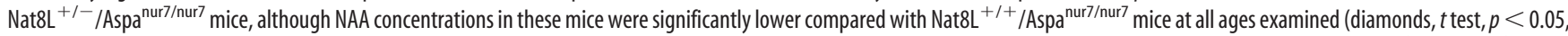
$n=3-6) . F$, Total brain concentration of NAAG was not altered at $\mathrm{P} 60$ in all analyzed genotypes. However, a statistically significant reduction of NAAG was observed in Nat $8 \mathrm{~L}^{+/+} /$Aspa $^{\text {nur }} /$ nur 7 and $\mathrm{Nat}_{\mathrm{L}} \mathrm{L}^{+/-} / \mathrm{Aspa}^{\text {nur7/nur7 }}$ mice at the age of 1 year compared with controls ( $t$ test, $\left.{ }^{*} p<0.05, n=3-6\right)$.

2011) with minor modifications. Frozen brain tissue samples were grounded under liquid nitrogen using a mortar and one-third of the homogenate from one hemisphere was resuspended in $500 \mu$ l of ice-cold $90 \%$ methanol, passed 10 times through a 21 gauge needle, and sonicated for $5 \mathrm{~min}$ in a water bath sonifier. Stable isotope-labeled $\left[{ }^{13} \mathrm{C} /{ }^{15} \mathrm{~N}\right]-\mathrm{NAA}$ and NAAG standards (Panatecs) were added and samples were incubated for $10 \mathrm{~min}$ at room temperature. Protein precipitates were sedimented by centrifugation for $10 \mathrm{~min}$ at $20,000 \times g$ and $4^{\circ} \mathrm{C}$ and the protein content in the pellet was determined. The supernatant was dried under vacuum and dissolved in $50 \mu \mathrm{l}$ of HPLC grade water. Insoluble material was 
A

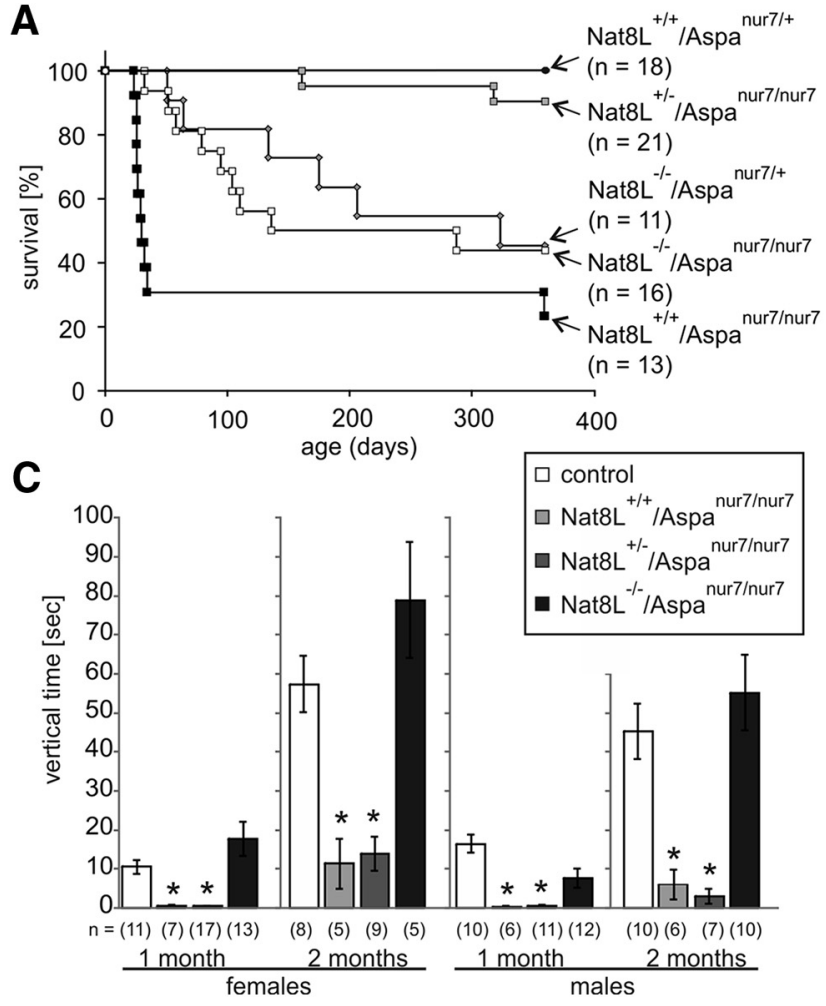

B
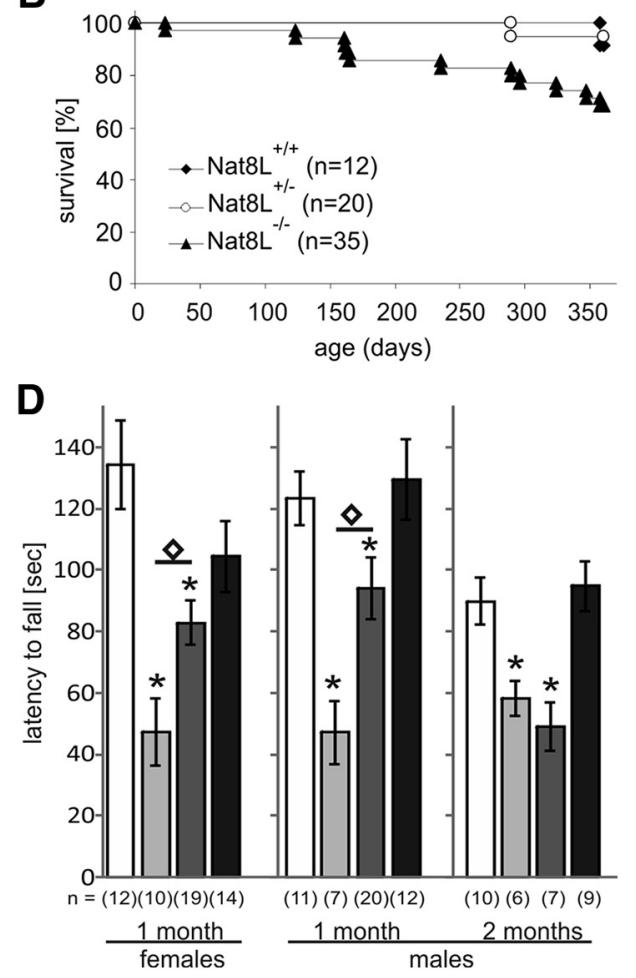

Figure 3. Nat8L $\mathrm{L}^{-/-} / \mathrm{Aspa}^{\text {nur7/nur7 }}$ mice have normal motor coordination capabilities, but survival time is not improved compared with Nat8L ${ }^{+/+} / \mathrm{Aspa}^{\text {nur } / \text { nur7 }}$ mice. $\boldsymbol{A}$, Kaplan-Meier plots

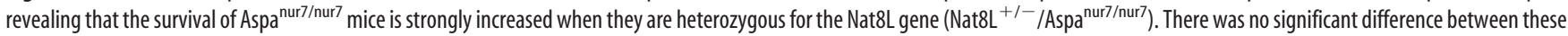
and Nat8 $\mathrm{L}^{+/+} / \mathrm{Aspa}^{\text {nur7/+}}$ mice (log-rank test, $p>0.05$ ). Mortality of Nat8L $\mathrm{L}^{-/-} / \mathrm{Aspa}^{\text {nur7/nur7 }}$ mice was comparable to that of Nat8L ${ }^{-/-} / \mathrm{Aspa}^{\text {nur } 7 /+}$ mice, indicating that premature death was not caused by NAA accumulation. Nevertheless, survival times of these mice were not significantly different from that of Nat8 $\mathrm{L}^{+/+} / \mathrm{Aspa}^{\text {nur7/nur7 }}$ mice (log-rank test, $\left.p>0.05\right)$. $\boldsymbol{B}$, Kaplan-Meier

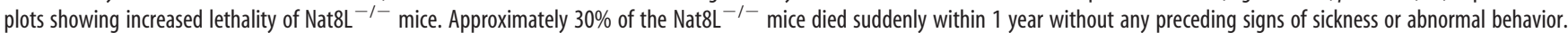

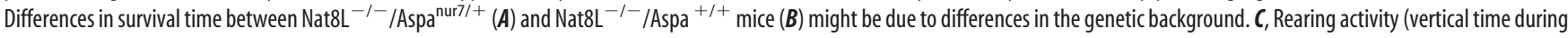
the 20 min test session) measured in the open field test. The test was performed with male and female mice of the indicated genotypes at 1 and 2 months of age. Data shown are the mean $\pm S E M$

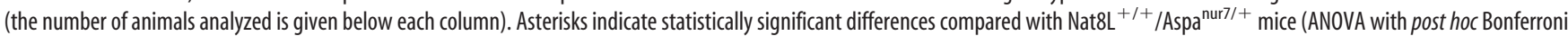
test; $\left.{ }^{*} p<0.05\right)$. There was no significant difference between Nat8L ${ }^{+/-} /$Aspa $^{\text {nur7/nur7 }}$ and Nat8 $\mathrm{L}^{+/+} / \mathrm{Aspa}^{\text {nur7/nur7 }}$ mice. $\boldsymbol{D}$, To examine motor coordination capability, accelerating rotarod tests

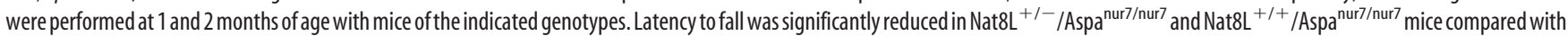

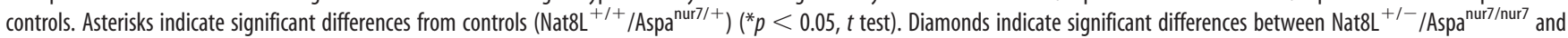
$\mathrm{Nat}^{+} \mathrm{L}^{+/+} / \mathrm{Aspa}^{\text {nur7/nur7 }}$ mice. Data shown are the mean \pm SEM (the number of animals analyzed is given below each column).

removed by centrifugation for $10 \mathrm{~min}$ at $20,000 \times g$ and $4^{\circ} \mathrm{C}$. Samples were analyzed by a tandem LC/MS spectroscopy method. For HPLC (HPLC 1200 series; Agilent Technologies), a column (organic acid resin $250 \times 4 \mathrm{~mm}$ sphere image; CS Chromatographie Service) with an organic acid resin, PS-DVB with a sulfonic acid changer, was used. The mobile phase consisted of $0.05 \%$ formic acid and absorbance was measured at $214 \mathrm{~nm}$. For equilibration, the column was washed with the mobile phase for $1 \mathrm{~h}$ at a flow rate of $1 \mathrm{ml} / \mathrm{min}$. The flow rate for all analysis was $0.5 \mathrm{ml} / \mathrm{min}$. ESI/MS spectra (ESI-MS HCTultra; Bruker Daltonics) were recorded in negative ion mode with auto/MS fragmentation. Eluate fractions from the HPLC were injected directly. Nitrogen was used as a drying gas at $350^{\circ} \mathrm{C}$. The collision gas was a mixture of helium with $3 \%$ argon. The capillary voltage was set to $4000 \mathrm{~V}$.

Histology, immunohistochemistry, and immunofluorescence. Mice were decapitated and brains were quickly removed. One hemisphere of each animal was fixed in Bouin's fixative (diluted 1:4 with PBS) overnight at $4^{\circ} \mathrm{C}$. Fixed tissues were properly washed in tap water and embedded in paraffin. Alternatively, the hemispheres were fixed in $4 \%$ PFA overnight at $4^{\circ} \mathrm{C}$ and washed in PBS after paraffin embedding. Brain sections were cut at $4 \mu \mathrm{m}$ using a Leica RM2155 microtome. After deparaffinization processed by a routine protocol, the sections were stained with H\&E for histological illustration. Luxol Fast Blue staining was used for revelation of myelin and myelinated axons. For both immunohistochemistry and immunofluorescence analysis, paraffin sections were deparaffinized, followed by epitope uncovering by heat-induced antigen retrieval in citrate buffer. For immunohistochemistry, paraffin sections were treated with $0.3 \%$ Triton $\mathrm{X}-100$ for $10 \mathrm{~min}$ and then blocked for $2 \mathrm{~h}$ with TBS containing $5 \%$ normal goat serum, $1 \%$ bovine serum albumin, and $0.1 \%$ Triton $\mathrm{X}-100$ at room temperature. Incubation with the primary antibodies was performed in blocking solution at $4^{\circ} \mathrm{C}$ overnight. After washing with TBS, bound primary antibodies were detected using Super Sensitive Link-Label IHC detection system (BioGenex) and 3,3'diaminobenzidine as a substrate. The sections were counterstained with hematoxylin, dehydrated, cleared with xylene, and mounted with DPX. For immunofluorescence analysis, sections were treated with sodium borohydride $(2 \mathrm{mg} / \mathrm{ml})$ for $10 \mathrm{~min}$, washed 3 times with PBS, and blocked for $1 \mathrm{~h}$ with PBS containing 5\% BSA and $0.4 \%$ Triton X-100 at room temperature. Incubation with the primary antibodies was done in PBS containing 1\% BSA and 0.1\% Triton X-100 overnight at $4^{\circ} \mathrm{C}$. Sections were washed with PBS and then incubated with the appropriate secondary antibody and DAPI for $90 \mathrm{~min}$ at room temperature. After washing with PBS, a saturated Sudan Black B solution in $70 \%$ ethanol was used to reduce autofluorescence. The sections were washed with PBS, water, and finally mounted with ProLong Gold antifade reagent (Life Technologies).

High-resolution light microscopy and transmission electron microscopy. Mice were killed by an overdose of anesthetics and immediately after death fixed by sequential transcardiac perfusion with first $30 \mathrm{ml}$ of $1 \%$ procaine in PBS and then $200 \mathrm{ml}$ of $6 \%$ glutardialdehyde and $1 \%$ procaine in PBS. After postfixation for at least $16 \mathrm{~h}$ in $6 \%$ glutardialdehyde, regions of interest were dissected, washed in buffer, postfixed in $1 \% \mathrm{OsO}_{4}$ 

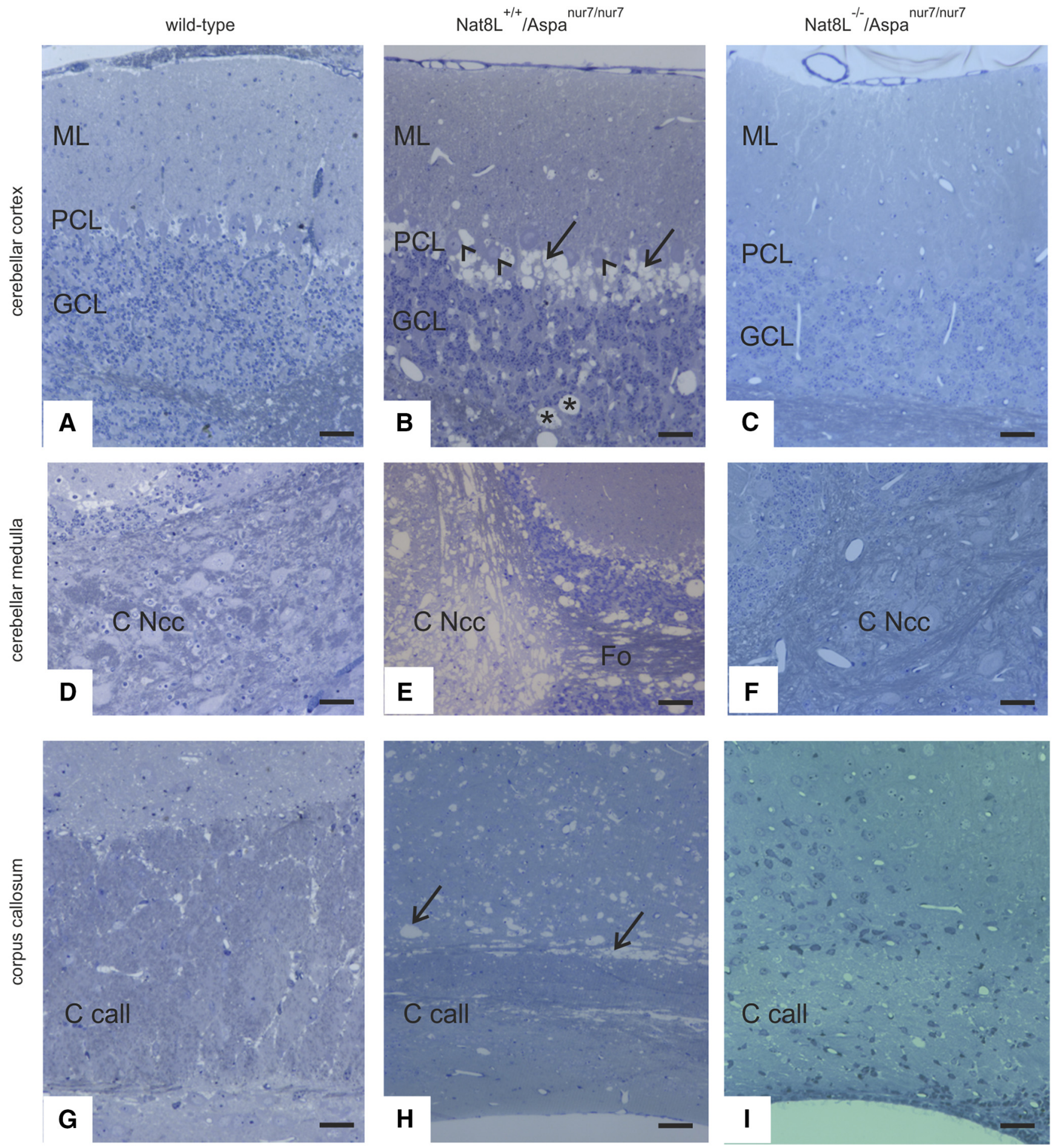

Figure 4. Histopathology of cerebellum and corpus callosum. Figure shows sections of the cerebellar cortex $(\boldsymbol{A}-\boldsymbol{C})$, cerebellar medulla $(\boldsymbol{D}-\boldsymbol{F})$, and corpus callosum $(\boldsymbol{G}-\boldsymbol{I})$ of $21-\mathrm{d}$-old mice of the indicated genotypes. Compared with wild-type $(\boldsymbol{A}), \mathrm{Nat}^{\mathrm{L}} \mathrm{L}^{+/+} / \mathrm{Aspa}^{\text {nur } / \text { nur7 }}$ cerebellum $(\boldsymbol{B})$ features vacuolic degeneration both within granule cell layer (GCL) and folial white matter (asterisks), but most prominently at the level of the Purkinje cell layer (PCL, arrows). Interestingly, the majority of Purkinje cell somata appear to be preserved (arrowheads), indicating that the degeneration seen here is confined to passing axons and possibly Bergmann glia cell bodies. In Nat8L ${ }^{-1-} / \mathrm{Aspa}^{\text {nur7/nur7 }}$ mice $(\boldsymbol{C})$, the effects on the cerebellar cortex are reversed to wild-type morphology. A

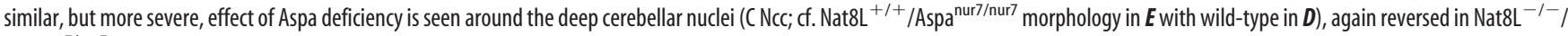
$\mathrm{Aspa}^{\text {nur7/nur7 }}$ mice $(\boldsymbol{F})$. Note that the severe degeneration seen in the medullary center of the cerebellum $(\boldsymbol{E})$ is only partially seen in the folial white matter (Fo in $\left.\boldsymbol{E}\right)$. Within the corpus callosum $(\boldsymbol{G}-\boldsymbol{I})$, lesions in $\mathrm{Nat8L^{+/+ }} / \mathrm{Aspa}^{\text {nur } / \text { nur }}$ are mainly observed at its dorsal aspect $(\boldsymbol{H}$, arrows), extending into the deeper layers of the cortex up to about layer IV. Again, degeneration is not seen in Nat8L ${ }^{-/-} / \mathrm{Aspa}^{\text {nur } / \text { nur7 }}$ mice (I). Scale bars, $50 \mu \mathrm{m}$.

for $2 \mathrm{~h}$, dehydrated in an ascending series of ethanol, and embedded in Spurr's resin using propylene oxide as an intermediate; the latter was chosen for its capacity to minimize shrinkage during embedding (Edwards et al., 2009). Blocks were cut at $1 \mu \mathrm{m}$ for semithin sections being stained with pyronine $\mathrm{G}$ and toluidine blue for high-resolution light microscopy. Selected regions were then recut at $70 \mathrm{~nm}$ and sections contrasted with uranyl acetate and lead citrate for transmission electron microscopy. 

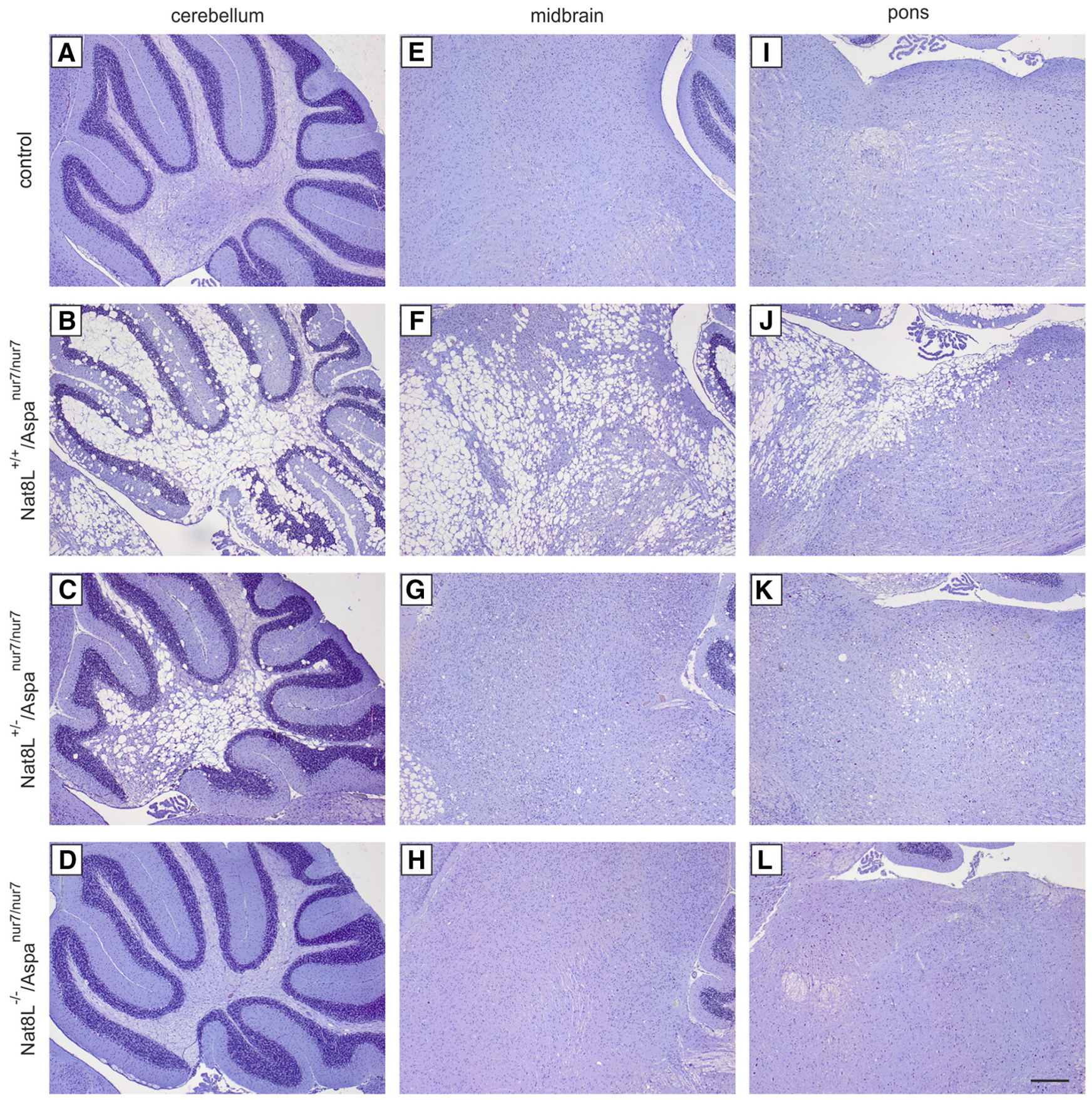

Figure 5. Less severe spongy degeneration in Aspa ${ }^{\text {nur } / \text { nur7 }}$ heterozygous for Nat8L. HE staining on sagittal paraffin-embedded brain sections of $\mathrm{Nat8L}^{+/+} / \mathrm{Aspa}^{\text {nur } / /+}(\mathrm{control})(\boldsymbol{A}, \boldsymbol{E}, \boldsymbol{I})$, $\mathrm{Nat8L}^{+/+} / \mathrm{Aspa}^{\text {nur } / \text { nur7 }}(\boldsymbol{B}, \boldsymbol{F}, \boldsymbol{J})$, Nat8L $^{+/-} / \mathrm{Aspa}^{\text {nur7/nur7 }}(\boldsymbol{C}, \boldsymbol{G}, \boldsymbol{K})$, and Nat8L $\mathrm{L}^{-1-} / \mathrm{Aspa}^{\text {nur//nur7 }}(\boldsymbol{D}, \boldsymbol{H}, \boldsymbol{L})$ mice at the age of 1 year. Extensive vacuolation was observed in cerebellum $(\boldsymbol{A}-\boldsymbol{D})$,

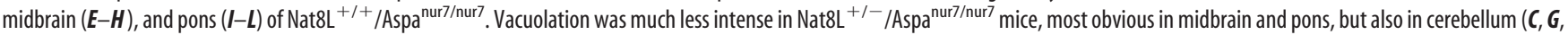
$\boldsymbol{K})$, and absent from Nat8L ${ }^{-/-} / \mathrm{Aspa}^{\text {nur } / \text { nur7 }}$ mice $(\boldsymbol{D}, \boldsymbol{H}, \boldsymbol{L})$. Scale bar, $200 \mu \mathrm{m}$.

NAA synthase activity. NAA synthase activity was measured as described previously (Truckenmiller et al., 1985) with minor modifications. Briefly, brain tissues were homogenized in $100 \mathrm{~mm}$ sodium phosphate, $\mathrm{pH} 6.8$, and homogenates were incubated in reaction mixture containing $100 \mathrm{~mm}$ sodium phosphate, $\mathrm{pH} 6.8,1 \mathrm{~mm} \mathrm{~L}-\left[{ }^{14} \mathrm{C}\right]-$ aspartate $(2 \mu \mathrm{Ci} / \mu \mathrm{mol})$, and $0.5 \mathrm{~mm}$ acetyl-coenzyme $\mathrm{A}$ in a total volume of $20 \mu \mathrm{l}$. The reactions were incubated at $37^{\circ} \mathrm{C}$ for $30 \mathrm{~min}$ and stopped by adding $20 \mu \mathrm{l}$ of ice-cold ethanol. After centrifugation $(10,000 \times g, 2 \mathrm{~min}), 5 \mu \mathrm{l}$ of the supernatant was applied to an HPTLC silica gel plate und the chromatogram was developed with a solvent system of chloroform/methanol/acetic acid (90:10:50). Radioactive signals were visualized using a Fuji Bioimager and quantified using AIDA software (Raytest). Protein concentrations were determined with the Bio-Rad DC protein assay. $\left[{ }^{14} \mathrm{C}\right]$-labeled aspartate was obtained from Hartmann Analytik.

WB analysis. Frozen brain tissue samples were grounded under liquid nitrogen using a mortar. Tissues were homogenized in ice-cold TBS buffer containing $5 \mathrm{~mm}$ EDTA, $1 \mathrm{~mm}$ PMSF, $1 \mu \mathrm{g} / \mathrm{ml}$ aprotinin, and $1 \mu \mathrm{g} / \mathrm{ml}$ leupeptin and centrifuged for $1 \mathrm{~h}$ at $150,000 \times g$ at $4^{\circ} \mathrm{C}$. The pellet containing membranes was resuspended in $1 \%$ SDS in PBS. After centrifugation for $20 \mathrm{~min}$ at $20,000 \times g$ at $4^{\circ} \mathrm{C}$, samples of the supernatant were separated by SDS-PAGE on $7.5 \%, 10 \%$, or $12.5 \%$ acrylamide gels and transferred onto nitrocellulose membranes by semidry blotting. Protein concentrations were determined with the 
cerebellum
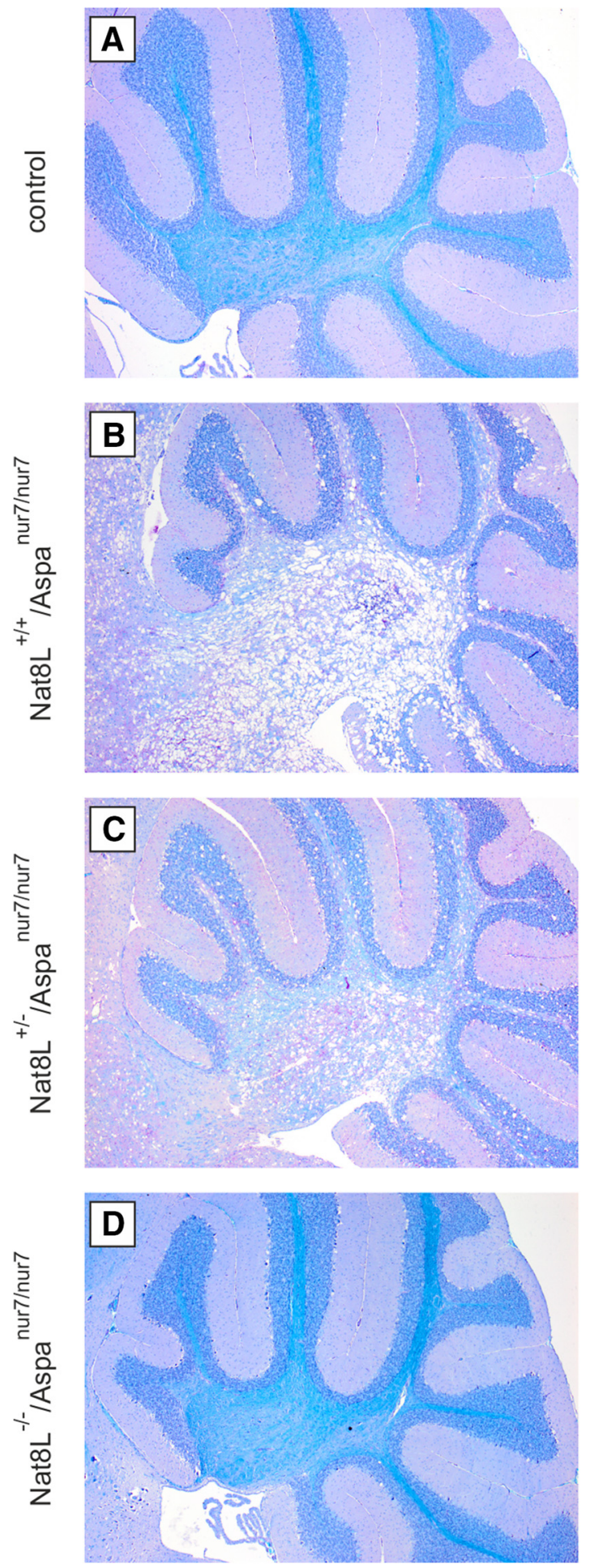

corpus callosum
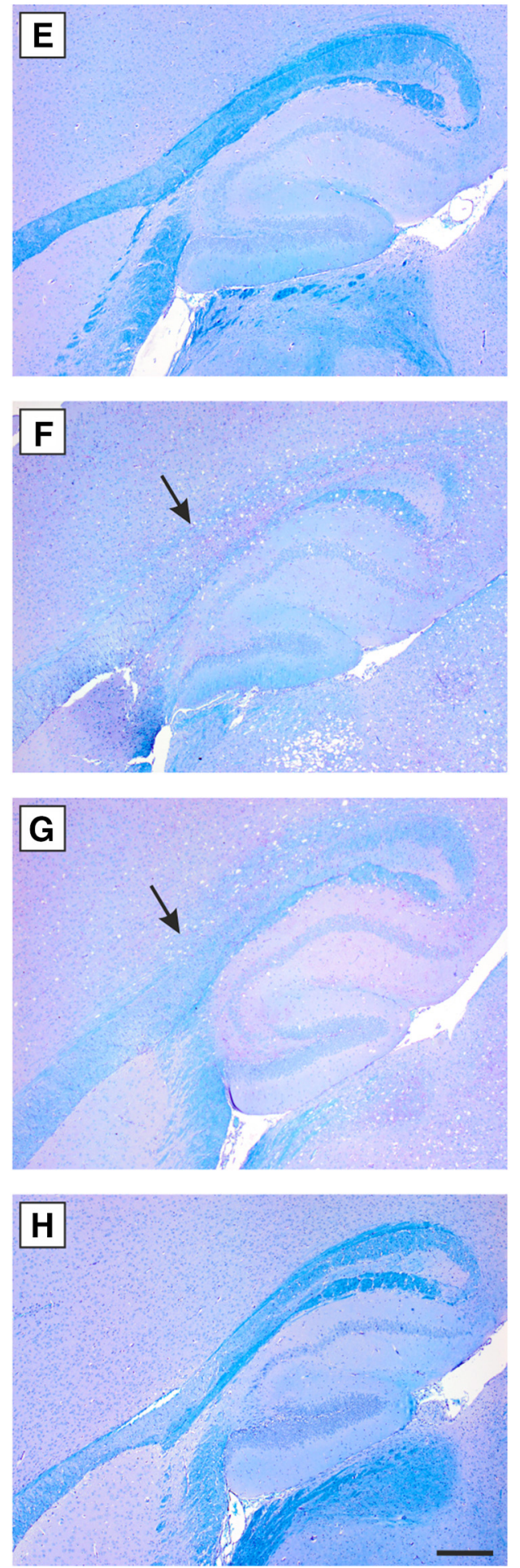

Figure 6. Luxol Fast Blue staining. $\boldsymbol{A}-\boldsymbol{H}$, Luxol Fast Blue staining of sagittal paraffin embedded brain sections of 60 -d-old animals. Spongy degeneration and vacuoles formation go along with demyelination in Nat8L ${ }^{+/+} / \mathrm{Aspa}^{\text {nur7/nur7 }}(\boldsymbol{B}, \boldsymbol{F})$ mice. Demyelination is demonstrated by less intense Luxol Fast Blue staining (arrows in $\boldsymbol{F}$ and $\boldsymbol{G}$ ) shown, for example, in the white matter of cerebellum $(\boldsymbol{A}-\boldsymbol{D})$ and corpus callosum $(\boldsymbol{E}-\boldsymbol{H})$ compared with control littermates $(\boldsymbol{A}, \boldsymbol{E})$. Nat8L ${ }^{-1-} / \mathrm{Aspa}^{\text {nur } / \text { nur }}(\boldsymbol{D}, \boldsymbol{H})$ did not show any indication of myelin loss compared with controls. Scale bar, $200 \mu \mathrm{m}$.

Bio-Rad DC protein assay using BSA as a standard. After blocking in $5 \%$ nonfat milk in TBS, membranes were incubated with primary antibodies overnight at $4^{\circ} \mathrm{C}$ in $5 \%$ nonfat milk in TBS. After washing in TBS containing $0.05 \%$ Tween 20 , membranes were incubated for 45 min in the dark with the appropriate DyLight 800- and DyLight 649-conjugated secondary antibodies. Bound antibodies were visualized and quantified using infrared fluorescence detection (Odyssey Imager System; Li-Cor Bioscience).

Lipid analysis. Frozen brain tissue samples were ground under liquid nitrogen using a mortar. Lipids were extracted as described previously 


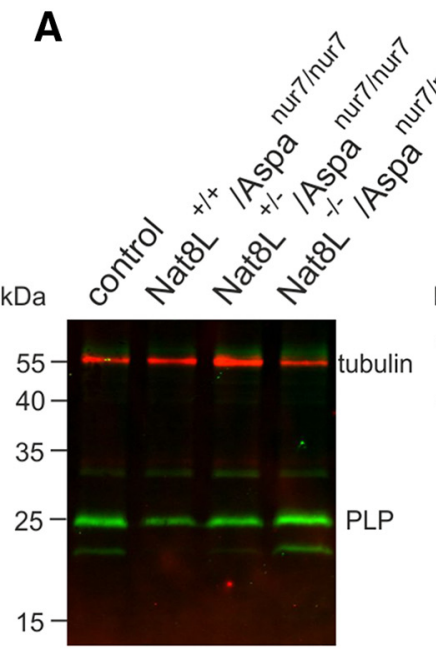

B

C
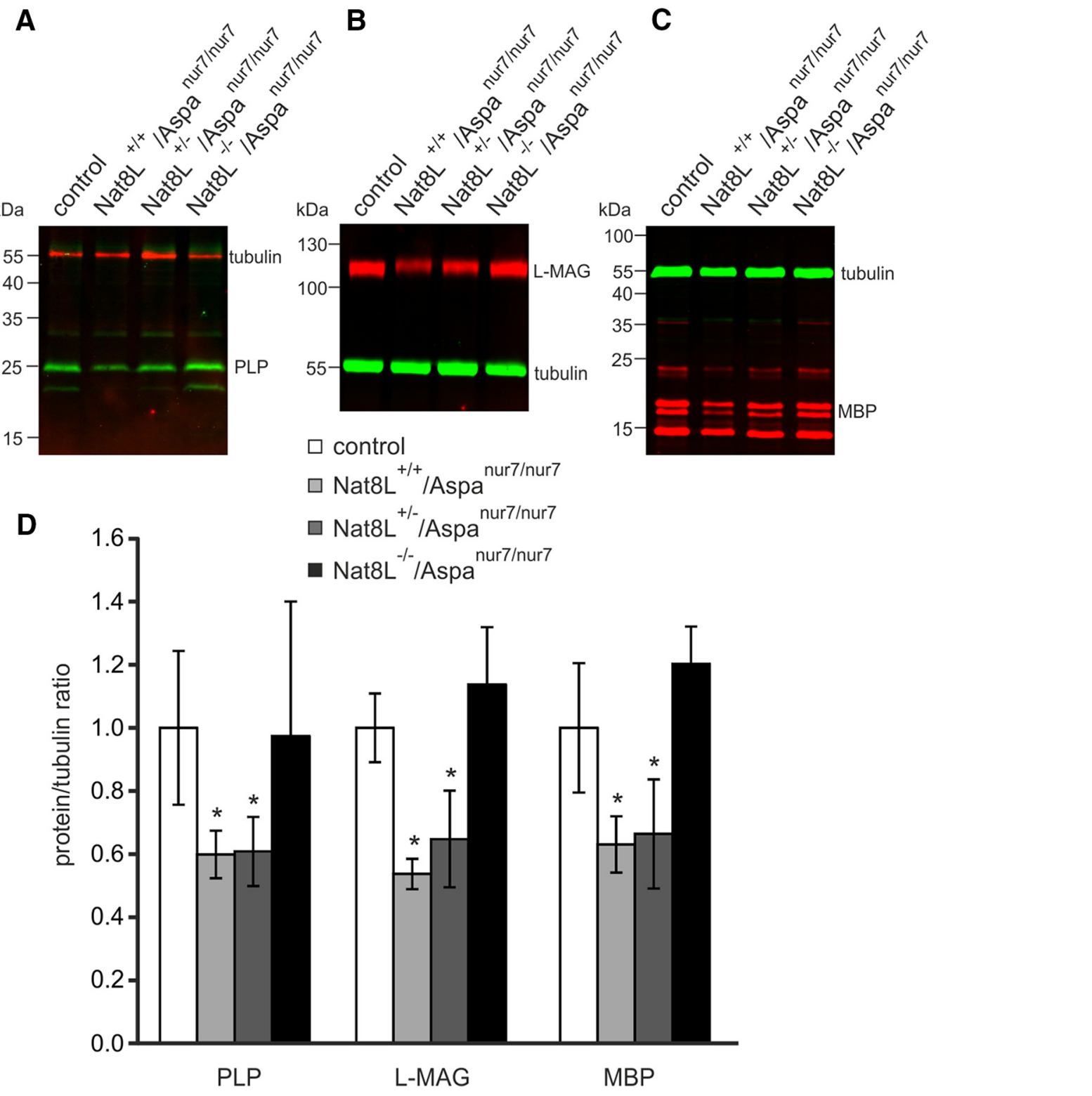

Figure 7. WB analysis of myelin proteins. The $60-\mathrm{d}-$ old Nat8L $\mathrm{L}^{+/+} / \mathrm{Aspa}^{\text {nur7/nur7 }}$ and Nat8L $\mathrm{L}^{+/-} / \mathrm{Aspa}^{\text {nur7/nur7 }}$ mice showed reduced levels of PLP $(\boldsymbol{A}, \boldsymbol{D}), \mathrm{L}-\mathrm{MAG}(\boldsymbol{B}, \boldsymbol{D})$, and MBP $(\boldsymbol{C}, \boldsymbol{D}) \operatorname{compared}$ with controls. In contrast, the amounts of these myelin proteins were not significantly reduced in Nat8L ${ }^{-1-} / \mathrm{Aspa}^{\text {nur } / \text { nur7 }}$ mice $\left({ }^{*} p<0.05, t\right.$ test; $\left.n=3-4\right)$.

(Yaghootfam et al., 2005). Lipids corresponding to $1 \mathrm{mg}$ of brain (wet weight) were loaded onto HPTLC silica gel 60 plates (Merck/Millipore) using an automatic TLC 4 sampler (CAMAG) and separated using chloroform/methanol/water $(65: 25: 4 ; \mathrm{v} / \mathrm{v} / \mathrm{v})$ as a solvent system. Lipids were visualized by spraying with $0.625 \mathrm{M}$ copper sulfate in $8 \%(\mathrm{v} / \mathrm{v})$ phosphoric acid, followed by heating at $180^{\circ} \mathrm{C}$ for $5 \mathrm{~min}$. Serial dilutions $(0.2-3 \mu \mathrm{g})$ of bovine galactosylceramide ( $\mathrm{GalC}$ ) and sulfatide standards (SigmaAldrich) were applied onto the same TLC plate as the samples and used to construct a standard curve. Lipids were quantified by densitometry using AIDA software (Raytest).

Myelin purification. Myelin was purified from brain by means of sucrose density gradient centrifugation as described previously (Zöller et al., 2008).

Behavioral analyses. Rotarod tests were done using an accelerating rotarod from TSE Systems with male and female mice of the following genotypes: $\mathrm{Nat}_{8 \mathrm{~L}} \mathrm{~L}^{+/+} / \mathrm{Aspa}^{\text {nur7/++}}, \mathrm{Nat} 8 \mathrm{~L}^{+/+} / \mathrm{Aspa}^{\text {nur7/nur7 }}, \mathrm{Nat} 8 \mathrm{~L}^{+/-} /$ Aspa $^{\text {nur7/nur7, }}$, and Nat8 $\mathrm{L}^{-1-} / \mathrm{Aspa}^{\text {nur7/nur7 }}$. On the first day, mice were acclimatized to the rotarod apparatus by placing them on the rod (rotating at a constant speed of $4 \mathrm{rpm}$ ) 2 times for $2 \mathrm{~min}$ with a $10 \mathrm{~min}$ break in between. Mice that fell off the rod during the 2 min were placed on the rod again (while timing was stopped). Mice that were unable to learn this task and fell off the rod repeatedly during the second 2 min training phase $\left(2 \mathrm{Nat} 8 \mathrm{~L}^{+/+} / \mathrm{Aspa}^{\text {nur } 7 / \text { nur7 }}\right.$ mice) or that repeatedly jumped off the $\operatorname{rod}\left(1 \mathrm{Nat} 8 \mathrm{~L}^{-1-} / \mathrm{Aspa}^{\text {nur7/nur7 }}\right.$ mouse) were excluded from the experiment. On the next day, mice were placed on the accelerating rod and speed was increased continuously from 4 to $40 \mathrm{rpm}$ within $5 \mathrm{~min}$. The time, the number of mice that remained on the rod was determined (cutoff $5 \mathrm{~min}$ ). The test was repeated two times with a $15 \mathrm{~min}$ break between trials and the mean of the three runs was calculated. The test runs were repeated on the following day. The assay was done with mice at an age of postnatal day 26 (P26)-P27 and P58-P60 (the same cohort of mice was used for both age groups). Open field tests were done with the same cohort of mice examined with the rotarod at an age of 1 month (P28-P30) and 2 months (P60-P70). The size of the open field box area (MED Associates) was $43 \times 43 \mathrm{~cm}^{2}$. The tests were performed between $4: 30$ and 6:30 P.M. Tests were started by placing the mouse in the center of the open field box under bright light (110 lux) and movement of the mouse was monitored for $20 \mathrm{~min}$. Thereafter, the mouse was returned into its home cage. The total activity (distance traveled), rearing ac- 

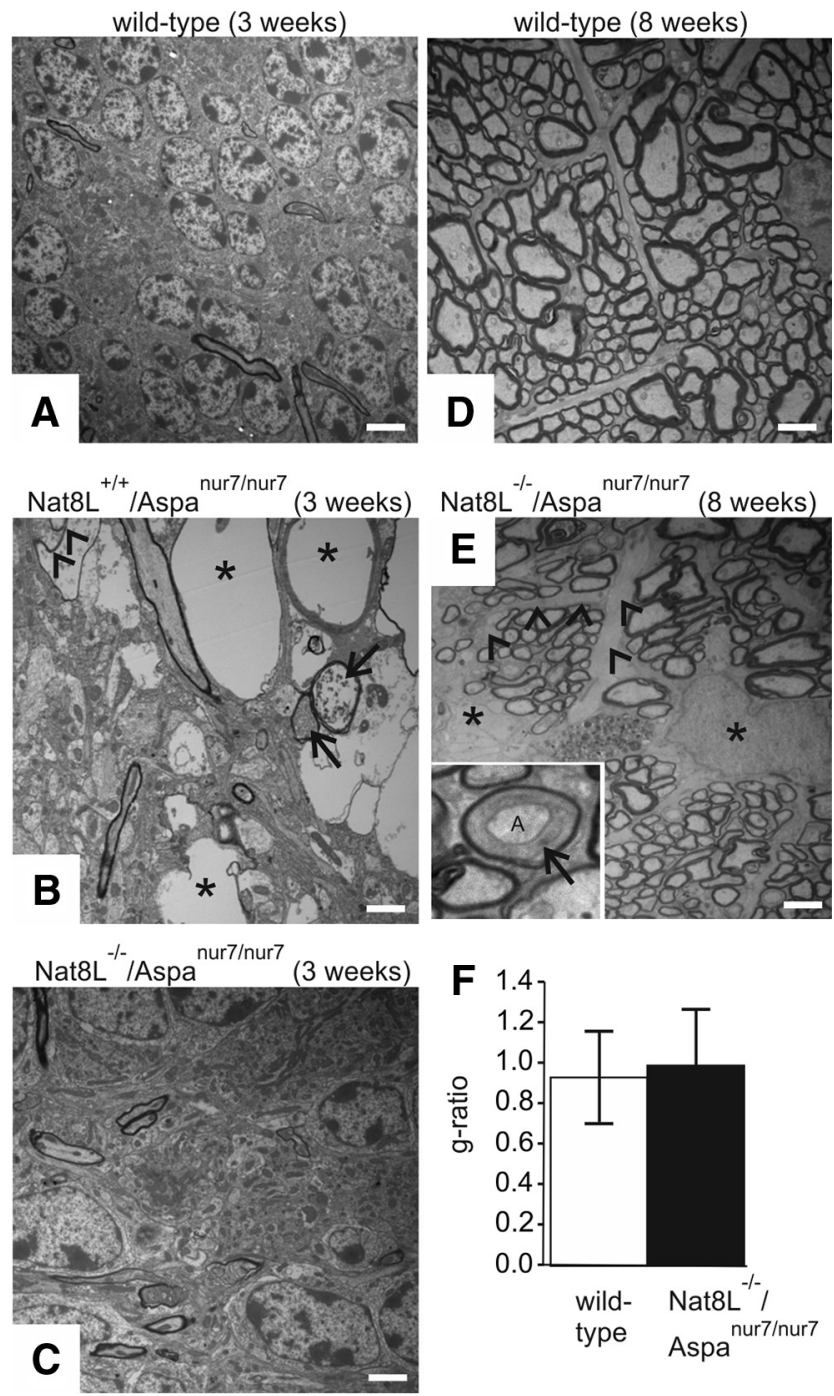

Figure 8. Ultrastructural analysis of CNS. TEM analysis of Nat8 $\mathrm{L}^{+/+} / \mathrm{Aspa}^{\text {nur7/nur7 }}$ mice reveals drastically swollen axons (asterisks in $\boldsymbol{B}$ ) without visible remainders of myelin sheaths (cerebellum, 3 weeks). Less severely affected axons ( $\boldsymbol{B}$, arrows) are filled with debris, but are still surrounded by apparently compressed myelin. Occasionally, intermediate forms are seen (B, arrowheads) in which fragments of myelin are visible along parts of the axonal perimeter. As already seen by light microscopy, defects are no longer visible in Nat8L ${ }^{-1-} / \mathrm{Aspa}^{\text {nur } / \text { /nur7 }}$ mice (C). To ascertain the formation of normal myelin sheaths in Nat8 $\mathrm{L}^{-1-} / \mathrm{Aspa}^{\text {nur } / \text { nur7 }}$ mice, we have chosen the optic nerve $(\boldsymbol{D}-\boldsymbol{F})$, which, due to its rather homogenous fiber population, would simplify detection of smaller g-ratio deviations (8-week-old mice were examined). Although myelinated fibers look normal again in Nat8L ${ }^{-1-} / \mathrm{Aspa}^{\text {nur7/nur7 }}$ mice (ff. $\boldsymbol{E}$ with wildtype controls shown in $\boldsymbol{D}$ ), we occasionally identified axons with minor structural aberrations of the surrounding myelin sheath, most notably axons (" $\mathrm{A}$ " in inset of $\boldsymbol{E}$ ) surrounded by an unusually broad internal mesaxon (arrow in inset). Furthermore, we observed enlargement of characteristically pale astrocytic somata (asterisks in $\boldsymbol{E}$ ) extending unusually broad processes $(\boldsymbol{E}$, arrowheads), tending to group neighboring axons into microfascicles. Despite these moderate structural abnormalities, the g-ratio in Nat8L $\mathrm{L}^{-1-} / \mathrm{Aspa}^{\text {nur } / \text { nur7 }}$ mice (black bar in $\boldsymbol{F}$ ) corresponds to that of wild-type mice (white bar in $\boldsymbol{F}$ ), demonstrating a normal thickness of myelin sheaths relative to axon caliber. Scale bars: $\boldsymbol{A}-\boldsymbol{C}, 3 \mu \mathrm{m} ; \boldsymbol{D}, \boldsymbol{E}, 1.5 \mu \mathrm{m} ; \boldsymbol{E}$, inset, $0.5 \mu \mathrm{m}$.

tivity (vertical time, vertical counts), and time spent in the center of the open field area were analyzed using Activity software (MED Associates). Additional open field tests were done with male Nat8L $\mathrm{L}^{-1-}$ and wild-type littermates of a separate colony that had not been crossed with the Aspa ${ }^{\text {nur7/nur7 }}$ mouse line at an age of 2-3 months.

Statistics. Comparison of survival rates was done by log-rank test. Behavioral data of the open field test were tested for significance by ANOVA and post hoc Bonferroni test. All other comparisons were done using Student's $t$ test. A significance level of $p<0.05$ was used for all tests.

\section{Results}

$\mathrm{Nat}^{-1-}$ mice lack NAA synthase activity but exhibit no loss of myelin

To enable the conditional knock-out of the NAA synthase gene (Nat8L), a targeting construct was generated in which exon 3 , which contains the catalytically essential domain, was flanked by loxP sites. The FRT-flanked neoselection marker and the lacZ reporter gene were introduced downstream of exon 3 (Fig. 1A). Heterozygous floxed F1 males were crossed with female mice expressing Cre recombinase (pgk-Cre) to generate Nat8Lheterozygous mice. Heterozygous F1 mice lacking cre recombinase were mated to obtain litters with all possible genotypes. Nat8 $\mathrm{L}^{-/-}$and Nat8 $\mathrm{L}^{+/-}$mice were born at the expected mendelian ratio. Cre-mediated deletion of exon 3 of the Nat8L gene was confirmed by Southern blot analysis and PCR (Fig. 1B). Northern blot analysis confirmed the absence of Nat8L expression in Nat8L $\mathrm{L}^{-1-}$ mice and significant reduced expression in heterozygous $\left(\mathrm{Nat} 8 \mathrm{~L}^{+/-}\right.$) mice (Fig. $1 C$ ), which correlated with the absence of and reduced NAA synthase activity in 2-month-old Nat8L $\mathrm{L}^{-1-}$ and Nat8L $\mathrm{L}^{+/-}$mice, respectively (Fig. 1D). Expression of Aspa was unaltered in the Nat $8 \mathrm{~L}^{-1-}$ mice. Expression of ATP: citrate lyase mRNA, which could potentially compensate a loss of NAA-derived acetyl-CoA for lipid synthesis during myelination and has been shown to be upregulated in brown adipose tissue in Nat8L ${ }^{-1-}$ mice (Pessentheiner et al., 2013), was not changed in brains of 20 -d-old Nat $8 \mathrm{~L}^{-1-}$ mice (Fig. $1 E$ ). The concentrations of NAA and NAAG in brain samples from 3-month-old mice of all three genotypes was determined by LC-MS using isotopelabeled $\left[{ }^{13} \mathrm{C} /{ }^{15} \mathrm{~N}\right]-\mathrm{NAA}$ and NAAG internal standards (Fig. $2 A, B)$. NAA levels in heterozygous mice were reduced to different degree in different CNS regions $(-17 \%$ in cortex, $-27 \%$ in cerebellum, $-40 \%$ in spinal cord) compared with wild-type littermates (Fig. 2C). NAA was undetectable in Nat8 $\mathrm{L}^{-1-}$ mice. In addition, the NAA-derived neuropeptide NAAG was absent in Nat8 $\mathrm{L}^{-1-}$ brains, but was not significantly reduced in Nat8 $\mathrm{L}^{+/-}$ mice (Fig. 2D). The expression of myelin genes such as PLP and MBP and MBP staining were not significantly altered in Nat8L $\mathrm{L}^{-1-}$ mice (Fig. $1 E, G$ ) and normal myelin content was confirmed by myelin isolation from total brain of 2-month-old mice (Fig. $1 F$ ). Consistent with these data, male Nat $8 \mathrm{~L}^{-/-}$mice exhibited no abnormal behavioral phenotype in the open field test (data not shown).

\section{Deletion of one Nat8L allele in Aspa ${ }^{\text {nur7/nur7 }}$ mice reduces NAA accumulation}

Because no obvious myelin phenotype was observed in Nat8 $\mathrm{L}^{-1-}$ mice, we examined whether absence of or reduced NAA synthesis in a $\mathrm{CD}$ mouse model could prevent the disease or improve its phenotype. Nat8 $\mathrm{L}^{-1-}$ mice were therefore crossed with the Aspa $^{\text {nur7/nur7 }}$ mouse line, which contains a nonsense mutation (Q193X) in the Aspa gene (Traka et al., 2008). We used a mass spectrometry method for NAA and NAAG quantification (Lodder-Gadaczek et al., 2011). As expected, NAA was strongly increased in $\mathrm{Nat} 8 \mathrm{~L}^{+/+} / \mathrm{Aspa}^{\text {nur7/nur7 }}$, compared with $\mathrm{Nat} 8 \mathrm{~L}^{+/+} /$ $\mathrm{Aspa}^{\text {nur7/+ }}$ mice (control) (Fig. 2E), but was not detectable in Nat8 $\mathrm{L}^{-1-} / \mathrm{Aspa}^{\text {nur7/nur7 }}$ mice (data not shown). Nat8L $\mathrm{L}^{+/-} / \mathrm{Aspa}^{\text {nur7/nur7 }}$ mice had significantly reduced NAA levels compared with Nat8 $\mathrm{L}^{+/+} / \mathrm{Aspa}^{\text {nur7/nur7 }}$ mice, but these were still higher than in controls. Interestingly, NAA concentrations increased strongly between P21 and P60, but slightly declined between P60 and 12 months in all genotypes (Fig. 2E). This suggests that substantial amounts of NAA, comparable to or even exceeding the amount of NAA synthesized, can be transported 

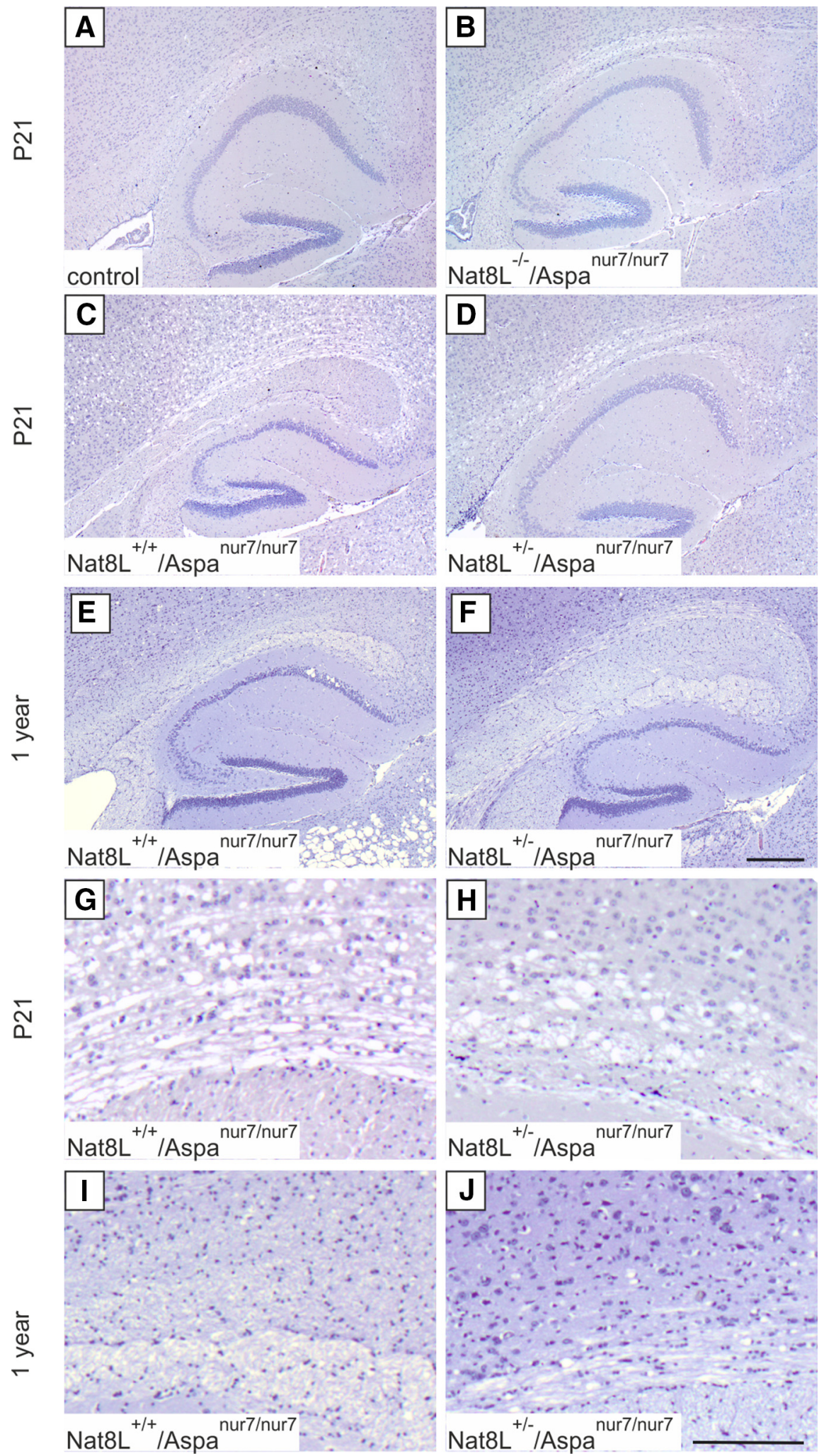

Figure 9. Reduced vacuolation in the corpus callosum of aged Aspa $a^{\text {nur7/nur7 }}$ mice. HE staining on sagittal paraffinembedded brain sections demonstrate a reversible phenotype in the corpus callosum of Nat8L ${ }^{+/+} / \mathrm{Aspa}^{\text {nur } 7 / \text { nur7 }}$ and Nat8 $\mathrm{L}^{+/-} / \mathrm{Aspa}^{\text {nur7/nur7 }}$ mice. At the age of P21, Nat8L ${ }^{+/+} / \mathrm{Aspa}^{\text {nur7/nur7 }}(\boldsymbol{C}, \boldsymbol{G})$ and Nat8L $\mathrm{L}^{+/-} / \mathrm{Aspa}^{\text {nur7/nur7 }}(\boldsymbol{D}, \boldsymbol{H})$ mice show a clear vacuolation in the white matter of corpus callosum compared with Nat8 $\mathrm{L}^{+/+} / \mathrm{Aspa}^{\text {nur } 7 /+}$ (control) $(\boldsymbol{A})$ and Nat8L $L^{-/-} /$Aspa $^{\text {nur7/nur7 }}(\boldsymbol{B})$ mice. At the age of 1 year, only a few small vacuoles were evident in this brain region and the histology appeared almost normal in Nat8L $\mathrm{L}^{+/+} / \mathrm{Aspa}^{\text {nur7/nur7 }}(\boldsymbol{E}, \boldsymbol{I})$ and Nat8L $\mathrm{L}^{+/-} / \mathrm{Aspa}^{\text {nur7/nur7 }}(\boldsymbol{F}, \boldsymbol{J})$ mice. Images $\boldsymbol{G}-\boldsymbol{J}$ show higher magnifications of the images $\boldsymbol{C}-\boldsymbol{F}$. Scale bars: $\boldsymbol{A}-\boldsymbol{F}, 200 \mu \mathrm{m} ; \boldsymbol{G}-\boldsymbol{J}: 100 \mu \mathrm{m}$. through the blood-brain barrier and possibly excreted in Aspa-deficient mice.

NAAG levels have been found to be increased in the urine of CD patients (Burlina et al., 1994). However, NMR measurements of NAAG did not show elevated NAAG levels in the brain of Aspadeficient mice (Surendran et al., 2004; Traka et al., 2008). Consistent with this, we found similar brain NAAG concentrations in all genotypes at P60. However, in 1-year-old Nat8L $\mathrm{L}^{+/+} / \mathrm{Aspa}^{\text {nur7/nur7 }}$ and Nat8L $\mathrm{L}^{+/-} /$Aspa $^{\text {nur7/nur7 }}$ mice, NAAG was significantly reduced by $25 \%$ and $22 \%$, respectively (Fig. $2 F$ ).

\section{Survival rate and behavior of Aspa $^{\text {nur7/nur7 }}$ mice in the absence or with reduced levels of NAA}

The majority of Nat $8 \mathrm{~L}^{+/+} / \mathrm{Aspa}^{\text {nur7/nur7 }}$ mice died within 4 weeks, consistent with previous reports on similar CD mouse models (Fig. 3A). This high mortality rate correlates well with the substantial increase in NAA in young animals (Fig. 2). Mortality of the mice surviving this period was, however, very low, which correlates with the absence of the further increase of NAA in the adult mice (see above). Nevertheless, these mice showed the typical symptoms of CD such as ataxic gait, tremors, and seizures. Surprisingly, Nat8L $\mathrm{L}^{-/-}$/ Aspa $^{\text {nur7/nur7 }}$ mice had a significantly reduced life span (Fig. 3A). This was also the case for Nat8 $\mathrm{L}^{-/-} / \mathrm{Aspa}^{+/+}$mice (Fig. 3B), indicating that premature death was independent of the Aspa genotype. These mice died suddenly without any obvious signs of illness, weight loss, or seizures. To investigate how sensitive mice are to a NAA reduction, we generated Aspa ${ }^{\text {nur7/nur7 }}$ mice with only one functional copy of the NAA synthase gene $\left(\mathrm{Nat} 8 \mathrm{~L}^{+/-} / \mathrm{Aspa}^{\text {nur7/nur7 }}\right)$. Nat8L $\mathrm{L}^{+/-} /$ Aspa $^{\text {nur7/nur7 }}$ mice developed similar symptoms as $\mathrm{Nat}^{+/+} / \mathrm{L}^{+/ \mathrm{pap}^{\text {nur7/nur7 }}}$, but their survival rate improved significantly compared with that of control mice. This shows that reduced NAA levels are beneficial for $\mathrm{CD}$ mice. In addition, when Nat8L $\mathrm{L}^{+/-} / \mathrm{Aspa}^{\text {nur7/nur7 }}$ are compared with $\mathrm{Nat} 8 \mathrm{~L}^{-/-} / \mathrm{Aspa}^{\text {nur7/nur7 }}$, the survival time is also significantly improved, suggesting a vital function of NAA that does not depend on its degradation by ASPA. In agreement with previous reports, body weights were reduced in $\mathrm{Nat} 8 \mathrm{~L}^{+/+} / \mathrm{Aspa}^{\text {nur7/nur7 }}$ mice (data not shown). In contrast, Nat8 $\mathrm{L}^{-/-}$/ Aspanur7/nur7 mice had normal body weights throughout development and body weights of $\mathrm{Nat} 8 \mathrm{~L}^{+/-} / \mathrm{Aspa}^{\text {nur7/nur7 }}$ 

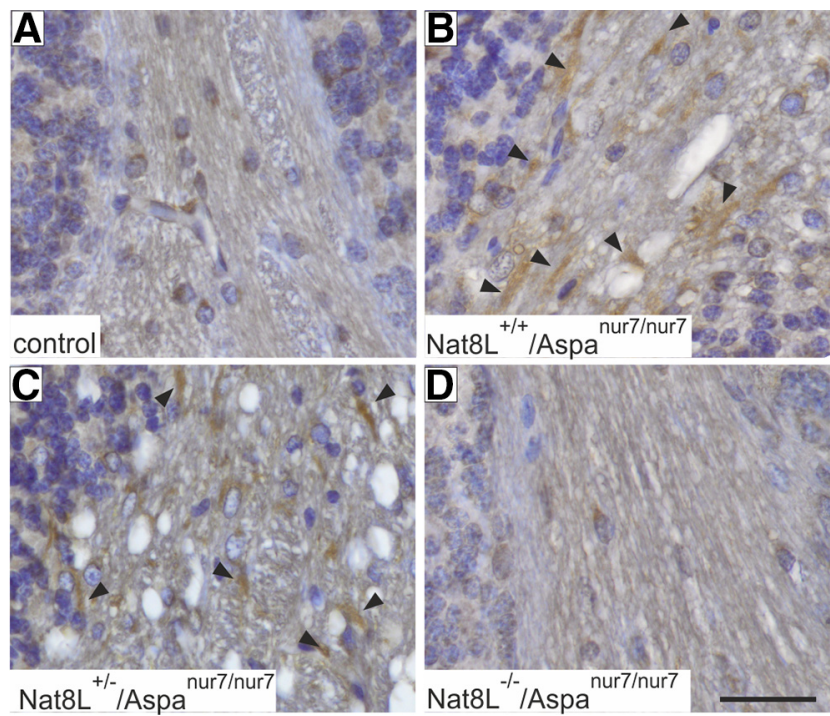

Figure 10. Nat8L deficiency prevents axon degeneration in Aspa ${ }^{\text {nur7/nur7 }}$ mice. Shown is immunohistochemical staining for APP on sagittal paraffin-embedded brain sections at the age of P60. Positive signals (arrowheads) were detectable in the cerebellar white matter of Nat8L $\mathrm{L}^{+/+} / \mathrm{Aspa}^{\text {nur7/nur7 }}(\boldsymbol{B})$ and Nat8L $\mathrm{L}^{+/-} / \mathrm{Aspa}^{\text {nur7/nur7 }}(\boldsymbol{C})$ mice, demonstrating axonal degeneration but none in control littermates $(\boldsymbol{A})$ or Nat8 $\mathrm{L}^{-/-} / \mathrm{Aspa}^{\text {nur7/nur7 }}$ mice (D). Scale bars, $20 \mu \mathrm{m}$.

mice were slightly reduced compared with controls, although they were significantly increased compared with $\mathrm{Nat} 8 \mathrm{~L}^{+/+} / \mathrm{Aspa}-$ nur7/nur7 mice (data not shown).

The behavior of all mice was examined in the open field test. Activity (total distance traveled) was reduced in both Nat8 $\mathrm{L}^{+/+} / \mathrm{Aspa}^{\text {nur7/nur7 }}$ and $\mathrm{Nat} 8 \mathrm{~L}^{+/-} / \mathrm{Aspa}^{\text {nur7/nur7 }}$ mice (data not shown), but was normal in Nat8 $\mathrm{L}^{-/-} / \mathrm{Aspa}^{\text {nur7/nur7 }}$ mice. A much more sensitive indicator for the CD phenotype was rearing activity (vertical time), which was strongly reduced in the Nat8 $\mathrm{L}^{+/+} / \mathrm{Aspa}^{\text {nur7/nur7 }}$ mice and to a similar extent also in the Nat $8 \mathrm{~L}^{+/-} / \mathrm{Aspa}^{\text {nur7/nur7 }}$ mice (Fig. $3 \mathrm{C}$ ). Again, performance of the Nat8 $\mathrm{L}^{-/-} / \mathrm{Aspa}^{\text {nur7/nur7 }}$ mice was not significantly different from control mice. In addition, accelerating rotarod tests were done with mice of all genotypes at 1 and 2 months of age using the same cohort of mice at both ages (Fig. 3D). Consistent with previous reports (Traka et al., 2008; Mersmann et al., 2011; Ahmed et al., 2013), latency to fall off the rotating rod was reduced by $\sim 50 \%$ in $\mathrm{Nat}^{2} \mathrm{~L}^{+/+} /$ Aspa $^{\text {nur7/nur7 }}$ mice compared with controls. In contrast, latency to fall of Nat8 $\mathrm{L}^{-/-} / \mathrm{Aspa}^{\text {nur7/nur7 }}$ mice was similar to controls. Therefore, motor coordination deficits of the Nat8 $\mathrm{L}^{+/+} / \mathrm{Aspa}^{\text {nur7/nur7 }}$ mice were apparently fully rescued by the additional Nat8L deficiency. Rotarod performance of the $\mathrm{Nat}^{+1-} \mathrm{L}^{+/} / \mathrm{Aspa}^{\text {nur7/nur7 }}$ mice was significantly improved at 1 month of age compared with $\mathrm{Nat} 8 \mathrm{~L}^{+/+} / \mathrm{Aspa}^{\text {nur7/nur7 }}$ mice, although it was still worse than in control mice. This was no longer the case at 2 months of age, which may be explained by the premature death of the majority of Nat8 $\mathrm{L}^{+/+} / \mathrm{Aspa}^{\text {nur7/nur7 }}$ mice and probably the survival of only those animals that were less severely affected by the disease. Together, the behavioral analyses revealed an apparently complete functional rescue in Nat8L $\mathrm{L}^{-/-} / \mathrm{Aspa}^{\text {nur7/nur7 }}$ mice, however, without a significantly increased survival time. In contrast, reducing NAA synthesis by deleting one functional Nat8L allele completely normalized the survival rate of Aspa ${ }^{\text {nur7nur7 }}$ mice and also resulted in a significantly improved behavioral phenotype.

\section{Nat8L deficiency in Aspa ${ }^{\text {nur7/nur7 }}$ mice prevents spongy degeneration and demyelination}

Analysis of brains (21-d-old mice) by high-resolution semithin sections using a protocol suitable to retain myelin lipids in the sections (Fig. 4) confirmed a massive spongy degeneration of white matter in the cerebellum of Nat8 $\mathrm{L}^{+/+} / \mathrm{Aspa}^{\text {nur7/nur7 }}$ mice, which was most pronounced around the deep cerebellar nuclei, but less prominent within the folial white matter (Fig. 4E). Within the corpus callosum, white matter degeneration mainly affected the immediate subcortical callosal surface, from here visibly extending along the myelinated thalamocortical fibers into the deeper layers of the isocortex up to about lamina 4 (Fig. $4 H$ ). In Nat8L $\mathrm{L}^{-/-} / \mathrm{Aspa}^{\text {nur7/nur7 }}$ mice, the effects on the cerebellum and corpus callosum were reversed to wild-type morphology (cf. Fig. $4 C, F, I$ and $A, D, G$ ). With increasing age, the spongy degeneration became more extensive in Nat8 $\mathrm{L}^{+/+} / \mathrm{Aspa}^{\text {nur7/nur7 }}$ mice, but remained absent from $\mathrm{Nat} 8 \mathrm{~L}^{-/-} / \mathrm{Aspa}^{\text {nur7/nur7 }}$ mice (Fig. 5). Remarkably, Nat8L $\mathrm{L}^{+/-} / \mathrm{Aspa}^{\text {nur7/nur7 }}$ mice (Fig. 5C,G,K) showed a less severe spongy degeneration compared with Nat8 $\mathrm{L}^{+/+} / \mathrm{Aspa}^{\text {nur7/nur7 }}$ mice (Fig. $5 B, F, J$ ). This difference was most obvious in the pons and midbrain (cf. Fig. $5 F, J$ and $G, K$ ), but was also visible in the cerebellum (cf. Fig. $5 B, C$ ) and other brain regions (data not shown). Vacuolation was not observed in the brains of Nat8 $\mathrm{L}^{-1-} / \mathrm{Aspa}^{\text {nur7/nur7 }}$ mice (Fig. $5 \mathrm{D}, H, L$ ).

Loss of myelin in Nat8 $\mathrm{L}^{+/+} / \mathrm{Aspa}^{\text {nur7/nur7 }}$ and Nat8 $\mathrm{L}^{+/-} /$ Aspa $^{\text {nur7/nur7 }}$ mice was examined using Luxol Fast Blue staining, which revealed widespread white matter degeneration in the cerebellum (Fig. 6B,C), corpus callosum (Fig. 6F,G), and other brain regions (data not shown), whereas myelin staining in Nat8L $^{-/-} /$Aspa $^{\text {nur7/nur7 }}$ mice (Fig. $6 D, H$ ) was comparable to controls (Fig. 6A,E). Myelin was further quantified in 2-monthold animals using WB analysis of major myelin proteins, showing significantly reduced levels of PLP, L-MAG, and MBP in Nat8 $\mathrm{L}^{+/+} / \mathrm{Aspa}^{\text {nur7/nur7 }}$ and Nat8 $\mathrm{L}^{+/-} / \mathrm{Aspa}^{\text {nur7/nur7 }}$ mice, but normal levels in Nat8 $\mathrm{L}^{-/-} / \mathrm{Aspa}^{\text {nur7/nur7 }}$ mice (Fig. 7).

On electron microscopic inspection (Fig. 8), vacuoles in Nat8L $\mathrm{L}^{+/+} / \mathrm{Aspa}^{\text {nur7/nur7 }}$ mice could be identified as dramatically swollen axons surrounded by compressed myelin layers, the latter often already fragmented (Fig. $8 B$ ). Vacuole formation and separation of lamellae within the myelin sheaths was not or only rarely encountered. In Nat8 $\mathrm{L}^{-/-} / \mathrm{Aspa}^{\text {nur7/nur7 }}$ mice, myelin structure appeared largely normal (Fig. 8C,E); however, unusually broad internal mesaxa were regularly encountered (Fig. 8E, inset), which were not observed in wildtype controls (Fig. 8D). In addition, we found enlargement of characteristically pale astrocytic somata (Fig. $8 E$ ) extending unusually broad processes that tended to group neighboring axons into microfascicles. Despite these structural changes, the g-ratio of myelinated axons in the optic nerve of 8-weekold of Nat8 $\mathrm{L}^{-1-} / \mathrm{Aspa}^{\text {nur7/nur7 }}:(0.99 \pm 0.28)$ and wild-type mice $(0.93 \pm 0.23)$ did not differ significantly (Fig. $8 F)$, demonstrating a normal thickness of myelin sheaths relative to axon caliber.

Vacuolation in the corpus callosum of $\mathrm{Nat} \mathrm{L}^{+/+} / \mathrm{Aspa}^{\text {nur7/nur7 }}$ (Fig. 9C,G) and Nat8L $\mathrm{L}^{+/-} / \mathrm{Aspa}^{\text {nur7/nur7 }}$ mice (Fig. 9D,H) at P21 was less intense than in other white matter tracts. Moreover, although spongy degeneration in general worsens with age in both Nat8L $\mathrm{L}^{+/+} / \mathrm{Aspa}^{\text {nur7/nur7 }}$ and Nat8L $\mathrm{L}^{+/-} / \mathrm{Aspa}^{\text {nur7/nur7 }}$ mice, vacuolation in the corpus callosum was less severe at P60 compared with P21 (data not shown) and almost undetectable in 1-yearold mice (Fig. 9E, F, I,J). In Nat8 $\mathrm{L}^{+/+} / \mathrm{Aspa}^{\text {nur7/nur7 }}$ mice, this might in part be explained by the premature death of more severely affected mice. This, however, cannot explain the same observation in 


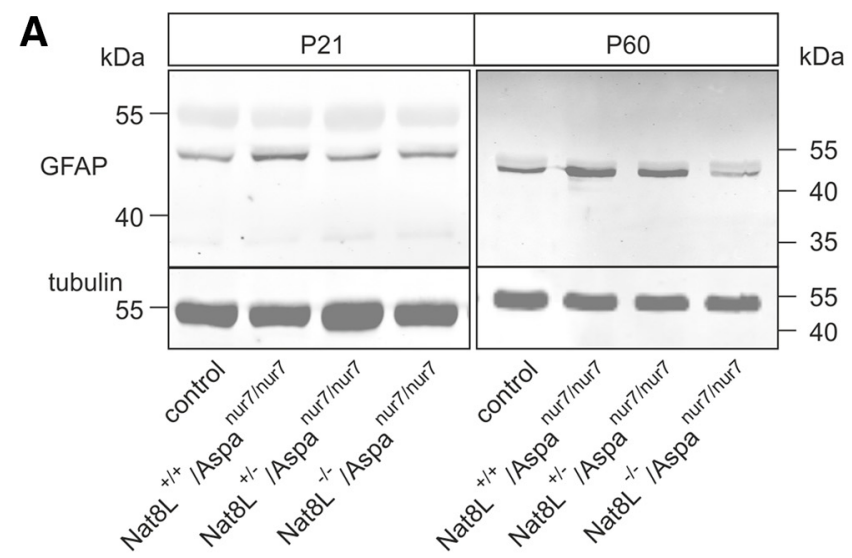

B

C

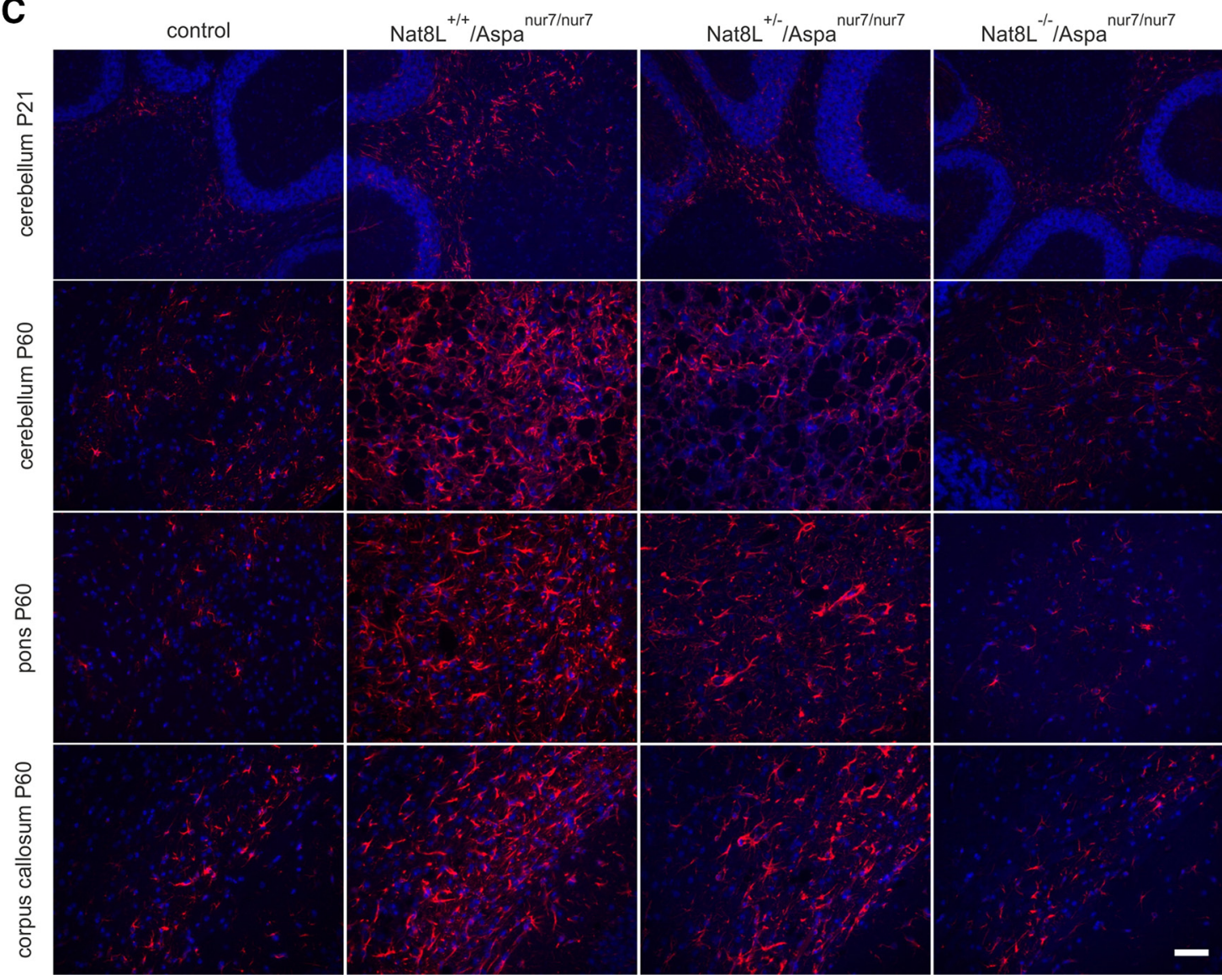

Figure 11. Nat8L deficiency prevents the massive astrogliosis in $\mathrm{Aspa}^{\text {nur7/nur7 }}$ mice. $A$, WB analysis of total brain homogenates indicated a strong increase in $\mathrm{GFAP}$ in Nat8L $\mathrm{L}^{+/+} / \mathrm{Aspa}^{\text {nur } / \text { nur7 }}$ and $\mathrm{Nat8L}^{+/-} / \mathrm{Aspa}^{\text {nur7/nur7 }}$ mice. Blots were reprobed with antibodies against $\alpha$-tubulin as a loading control. B, Densitometric quantification of GFAP WBs showed a statistically significant elevation of GFAP in Nat8L $\mathrm{L}^{+/+} / \mathrm{Aspa}^{\text {nur } / \text { nur7 }}$ and Nat8L ${ }^{+/-} / \mathrm{Aspa}^{\text {nur } 7 / \text { nur7 }}$ mice at P60. GFAP signals were normalized to tubulin and the mean of controls was set to $1\left({ }^{*} p<0.05, t\right.$ test; $\left.n=3\right)$. C, GFAP immunofluorescence staining confirmed increased GFAP expression and indicated a less severe GFAP upregulation in some brain regions (e.g., cerebellum) of Nat8L ${ }^{+/-} / \mathrm{Aspa}^{\text {nur }} / / \mathrm{nur} 7 \mathrm{compared}$ with Nat8L $\mathrm{L}^{+/+} / \mathrm{Aspa}^{\text {nur7/nur7 }}$ mice. Scale bar, $100 \mu \mathrm{m}$.

Nat8L $\mathrm{L}^{+/-} / \mathrm{Aspa}^{\text {nur7/nur7 }}$ mice, which had an almost normal survival rate at least until 1 year of age (Fig. $3 A$ ). Therefore, it seems possible that spongy degeneration is reversible in less affected regions.

\section{Nat8L deficiency prevents axon degeneration in Aspa ${ }^{\text {nur7/nur7 }}$} mice

Aspa $^{\text {nur7/nur7 }}$ mice exhibit significant axonal degeneration (Traka et al., 2008), which might be secondary to myelin degeneration. Conversely, because of the high concentration of NAA in axons (Bjartmar et al., 2002), its absence in neurons may also affect axonal integrity directly. The electron micro- scopic examination shown in Figure 8 confirmed axon degeneration in $\mathrm{Nat} 8 \mathrm{~L}^{+/+} / \mathrm{Aspa}^{\text {nur7/nur7 }}$ mice (Fig. $8 B$ ) and indicated its absence from Nat8 $\mathrm{L}^{-/-} / \mathrm{Aspa}^{\text {nur7/nur7 }}$ mice (Fig. $8 C, E)$. This was further confirmed by APP staining, which revealed axonal degeneration in white matter tracts in the cerebellum of $\mathrm{Nat} 8 \mathrm{~L}^{+/+} / \mathrm{Aspa}^{\text {nur7/nur7 }}$ mice (Fig. 10B) and Nat8L $\mathrm{L}^{+/-} / \mathrm{Aspa}^{\text {nur7/nur7 }}$ mice (Fig. $10 \mathrm{C}$ ), but not in $\mathrm{Nat}^{-1-} \mathrm{L}^{-/}$ Aspa $^{\text {nur7/nur7 }}$ mice (Fig. 10D) or controls (Fig. 10A). Therefore, the absence of NAA seems not to impair axonal integrity and axon loss in CD mice appears to be secondary to myelin degeneration. 
Nat8L deficiency prevents the massive astrogliosis in Aspa ${ }^{\text {nur7/nur7 }}$ mice

Because the electron microscopic examination revealed enlarged astrocytic somata with unusual broad processes in the optic nerve (Fig. $8 E$ ), we investigated to what extent astrogliosis is reverted in Nat8L $\mathrm{L}^{-/-} / \mathrm{Aspa}^{\text {nur7/nur7 }}$ compared with Nat8L $\mathrm{L}^{+/+} / \mathrm{Aspa}^{\text {nur7/nur7 }}$ mice. Analysis at $\mathrm{P} 21$ and $\mathrm{P} 60$ revealed a strong increase in GFAP staining in $\mathrm{Nat} \mathrm{L}^{+/+} / \mathrm{Aspa}^{\text {nur7/nur7 }}$ and $\mathrm{Nat} 8 \mathrm{~L}^{+/-} / \mathrm{Aspa}^{\text {nur7/nur7 }}$ mice (Fig. 11). GFAP signals in Nat8 $\mathrm{L}^{-/-} / \mathrm{Aspa}^{\text {nur7/nur7 }}$ mice, however, were similar to control mice. To quantify astrogliosis, WB analyses were done in parallel, confirming the immunofluorescence data showing a significant increase in GFAP at P60 in Nat8 $\mathrm{L}^{+/+} / \mathrm{Aspa}^{\text {nur7/nur7 }}$ and $\mathrm{Nat} 8 \mathrm{~L}^{+/-} /$ Aspa ${ }^{\text {nur7/nur7 }}$ mice, but not in Nat8 $\mathrm{L}^{-1-}$ / Aspa $^{\text {nur7/nur7 }}$ mice (Figs. $11 A, B$ ). Therefore, the widespread massive astrogliosis found in Aspanur7/nur7 mice depends mainly on NAA accumulation and is secondary to the spongy myelin degeneration.

\section{Nat8L $L^{-/-} /$Aspa $^{\text {nur7/nur7 }}$ mice exhibit normal sphingolipid composition}

Previous studies demonstrated significant changes in the myelin lipid composition in Aspa-deficient mice and tremor rat (Madhavarao et al., 2005; Traka et al., 2008; Wang et al., 2009). In particular, a strong reduction in the concentration of nonhydroxylated fatty acid containing GalC (NFA-GalC) was observed, which was viewed as an argument for the hypothesis that NAA-derived acetate is required for efficient myelin lipid synthesis (Ledeen et al., 2006). Confirming these data, TLC analysis of brain lipids showed strong reduction of NFA-GalC in Nat8L $\mathrm{L}^{+/+}$/ Aspa $^{\text {nur7/nur7 }}$ mice at P21 and P60, whereas 2-hydroxylated fatty acid-containing GalC (HFA-GalC) levels were reduced to a lesser extent at P60 only (Fig. 12). Sulfatide was also slightly reduced (whether in this case also only NFA-sulfatide was affected could not be examined, because NFA- and HFA-sulfatide are not separated under standard TLC conditions). Loss of GalC and sulfatide was less pronounced in Nat8 $\mathrm{L}^{+/-} / \mathrm{Aspa}^{\text {nur7/nur7 }}$ mice. Moreover, sphingolipid levels in Nat8 $\mathrm{L}^{-1-} / \mathrm{Aspa}^{\text {nur7/nur7 }}$ mice were not different from control mice, indicating that the reduction of myelin-specific sphingolipids in $\mathrm{Nat} 8 \mathrm{~L}^{+/+} / \mathrm{Aspa}^{\text {nur7/nur7 }}$ mice is not due to an insufficient supply of acetyl groups by NAA.

\section{Discussion}

ASPA deficiency causes a massive progressive spongy degeneration and loss of myelin in CD patients (Canavan, 1931) and corresponding mouse models (Matalon et al., 2000; Surendran et al., 2005; Traka et al., 2008). Different hypotheses to explain the pathology of CD have been proposed (for review, see Hoshino and Kubota, 2014). The results presented here show clearly that the absence of NAA hydrolysis products is not responsible for CD because the hallmarks of the disease (spongy degeneration, loss of myelin, and axon degeneration) were not observed in Nat8 $\mathrm{L}^{-1-}$ mice. Moreover, the lack of NAA leads to an apparently complete
B
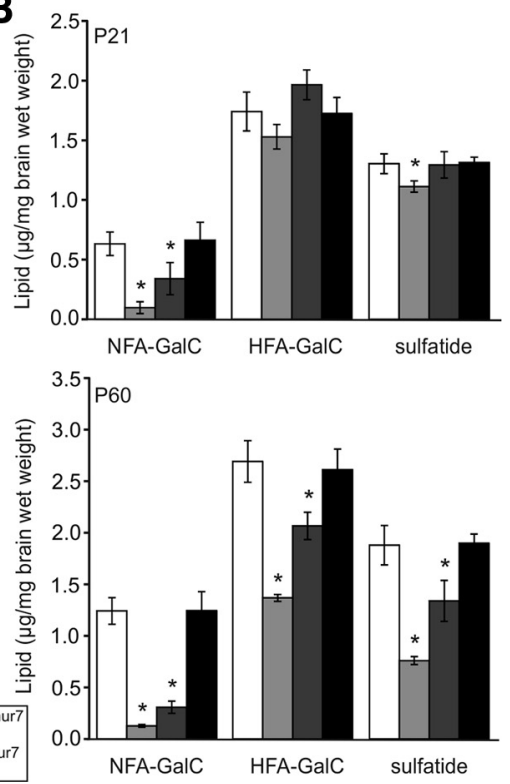

Figure 12. Myelin sphingolipid levels are normalized in Aspa ${ }^{\text {nur7/nur7 }}$ mice with an additional Nat8L deficiency. $\boldsymbol{A}$, Lipids were isolated from total brain of Nat8L $\mathrm{L}^{+/+} / \mathrm{Aspa}^{+/+}$or Nat8L ${ }^{+/+} / \mathrm{Aspa}^{\text {nur7/+ }}$ (control), Nat8L $\mathrm{L}^{+/+} / \mathrm{Aspa}^{\text {nur7/nur7 }}, \mathrm{Nat8L}^{+/-} /$ image is shown. $\boldsymbol{B}$, Quantitative analysis of the lipids demonstrate a statistically significant reduction in NFA-GalC in Nat8 $\mathrm{L}^{+/+} /$ Aspa $^{\text {nur7/nur7 }}$ and Nat8L $\mathrm{L}^{+/-} / \mathrm{Aspa}^{\text {nur7/nur7 }}$ mice, but not in Nat8L $\mathrm{L}^{-/-} / \mathrm{Aspa}^{\text {nur7/nur7 }}$ mice, compared with control mice. At P21, sufatide was only reduced in Nat8 $\mathrm{L}^{+/+} / \mathrm{Aspa}^{\text {nur7/nur7 }}$ mice. At P60, all quantified sphingolipids were significantly reduced in both, - $/ \mathrm{Aspa}^{\text {nur7/nur7 }}$ and Nat8L ${ }^{+/-} / \mathrm{Aspa}^{\text {nur7/nur7 }}$ mice compared with control littermates, demonstrating demyelination and the worsened phenotype from P21 to P60. There was no statistically significant difference between Nat8L ${ }^{-/-} / \mathrm{Aspa}^{\text {nur } 7 / \mathrm{nur}^{2}} \mathrm{mice}^{\mathrm{i}}$ and control mice ( ${ }^{*} p<0.05, t$ test, $\left.n=3-4\right)$.

reversal of the Canavan pathology in Aspa-deficient mice, indicating that the presence of high NAA concentrations is toxic and causal for the demyelination and axonal degeneration found in CD. Similar results were recently presented by Guo et al. (2015). However, although myelin sheaths of Nat8 $\mathrm{L}^{-/-} / \mathrm{Aspa}^{\text {nur7/nur7 }}$ mice in general appeared normal in our study (in agreement with Guo et al., 2015), which we could further substantiate by their normal g-ratio, we occasionally observed myelinated axons with minor structural abnormalities. Although the cause for these unusually thickened internal mesaxa is currently not clear, it is a first indication for an important role of NAA (or NAA-derived peptides such as NAAG) in the axon-oligodendrocyte interaction. Whether the observed structural changes play a role in the unexpected finding that the reversal of the spongy myelin degeneration by NAA deficiency did not improve survival times of Aspa $^{\text {nur7/nur7 }}$ mice requires further study. Nevertheless, it strongly argues that NAA has some yet unrevealed vital function. With respect to a therapeutic inhibition of NAA synthase, this cannot be ignored. To investigate how well a reduction in NAA levels is tolerated, we generated mice with only one functional allele of the Nat8L gene. Compared with Nat8L $\mathrm{L}^{+/+} / \mathrm{Aspa}^{\text {nur7/nur7 }}$ mice, these animals (Nat8 $\mathrm{L}^{+/-} / \mathrm{Aspa}^{\text {nur7/nur7 }}$ ) accumulated less NAA, which correlated with a significantly improved phenotype. The amelioration of motor coordination in the rotarod test in Nat8L $\mathrm{L}^{+/-} / \mathrm{Aspa}^{\text {nur7/nur7 }}$ compared with $\mathrm{Nat} 8 \mathrm{~L}^{+/+} / \mathrm{Aspa}^{\text {nur7/nur7 }}$ mice, however, was only transient and disappeared at 2 months of age despite a less pronounced spongy degeneration in the former genotype. Possibly, axon and myelin integrity is already substan- 
tially affected in Aspa-deficient mice before a widespread massive vacuolation (because it is seen in 2-month-old $\mathrm{Nat} 8 \mathrm{~L}^{+/+} / \mathrm{Aspa}^{\text {nur7/nur7 }}$ mice) is visible. Consistent with this, myelin protein levels were reduced to almost the same extent in both Nat8L $\mathrm{L}^{+/-} / \mathrm{Aspa}^{\text {nur7/nur7 }}$ and Nat8L $\mathrm{L}^{+/+} / \mathrm{Aspa}^{\text {nur7/nur7 }}$ mice.

Because all Nat8L $\mathrm{L}^{+/+} / \mathrm{Aspa}^{\text {nur7/nur7 }}$ mice surviving beyond 4 weeks survived for at least 1 year, it seems that reducing NAA synthesis at a critical period of 3-4 weeks of age, when Nat8L expression and NAA synthesis reach a maximum, may be sufficient to massively extend the lifespan of Aspa-deficient mice. Consistent with this, Ahmed et al. (2013) showed that Aspa delivery by a single injection of a recombinant adeno-associated virus as late as P20 prevented early death and alleviated CD symptoms in Aspa-deficient mice. Nat8L $\mathrm{L}^{+/-} / \mathrm{Aspa}^{\text {nur7/nur7 }}$ mice may serve as a new mouse model for late-onset forms of $\mathrm{CD}$ and, furthermore, can be used to study the efficacy of late therapeutic interventions. Apparently normal myelination in $\mathrm{Nat}_{8} \mathrm{~L}^{-1-}$ and Nat8L $\mathrm{L}^{-/-} / \mathrm{Aspa}^{\text {nur7/nur7 }}$ mice is also consistent with data from the only known patient with a defect in the Nat8L gene (Martin et al., 2001). According to the mutation in this patient (a 19 bp deletion), it can be assumed that he completely lacks NAA synthase activity (Wiame et al., 2009). Nevertheless, MRI scans revealed only minor changes in the white matter of this patient (Martin et al., 2001).

Different studies showed that acetyl groups derived from NAA are incorporated into myelin lipids (D'Adamo and Yatsu, 1966; Chakraborty et al., 2001). However, normal levels of myelin lipids, especially the major myelin sphingolipids GalC and sulfatide, in Nat8 $\mathrm{L}^{-/-} /$Aspa $^{\text {nur7/nur7 }}$ mice show clearly that NAA is not essential for myelin lipid synthesis. Nevertheless, this observation does not exclude the possibility that efficient remyelination under pathological conditions may partly depend on, or be improved by, acetate supply via NAA. This hypothesis could explain why acetate therapy alleviates symptoms in Aspa-deficient mice (Arun et al., 2010). The significantly stronger reduction of NFAGalC compared with HFA-GalC in Aspa-deficient mice or tremor rat (Ledeen et al., 2006; Traka et al., 2008; Wang et al., 2009) might be due to differential distribution of these two lipids within different myelin domains and higher susceptibility to the toxic effect of NAA of NFA-GalC-enriched myelin domains.

NAA concentrations strongly increased in Aspa ${ }^{\text {nur7/nur7 }}$ mice until P60, which correlates with the upregulation of NAA synthase activity during early postnatal development, as expected. Thereafter, however, NAA did not further increase, but rather its concentration slightly declined not only in controls, but also in $\mathrm{Nat} \mathrm{L}^{+/+} / \mathrm{Aspa}^{\text {nur7/nur7 }}$ and Nat8L $\mathrm{L}^{+/-} / \mathrm{Aspa}^{\text {nur7/nur7 }}$ mice. This is possibly due to a lower NAA synthase activity in adult mice, together with an efficient transport of NAA through the bloodbrain barrier and excretion. Strongly elevated NAA levels in the urine of CD patients ( $>50$-fold increase in urine NAA) and CD mouse models have been reported (Matalon et al., 1988, 2006). Because NAA was measured in total brain, however, continued white matter accumulation of NAA in adult mice cannot be excluded and is in fact likely because spongy degeneration deteriorates in different brain regions such as the cerebellum or medulla after P60 in Aspa ${ }^{\text {nur7/nur7 }}$ mice (Traka et al., 2008). Because axons contain high amounts of NAA (Bjartmar et al., 2002), the decline of NAA levels in Aspa-deficient brains could in part also be the result of axonal degeneration. This could also explain the observed changes in the NAA-derivative NAAG. Although NAAG was not increased in younger mice (P60), in agreement with previous reports (Surendran et al., 2004; Traka et al., 2008), the decreased NAAG levels in 1-year-old Nat8L $\mathrm{L}^{+/+} / \mathrm{Aspa}^{\text {nur7/nur7 }}$ and
Nat8L $\mathrm{L}^{+/-} /$Aspa $^{\text {nur7/nur7 }}$ mice possibly reflect axonal degeneration, which worsens significantly with age (Traka et al., 2008).

The rescue of early lethality, partially improved behavioral phenotype, and alleviated spongy degeneration in Nat8 $\mathrm{L}^{+/-}$/ Aspa $^{\text {nur7/nur7 }}$ mice compared with the conventional Aspa ${ }^{\text {nur7/nur7 }}$ mice indicate that the severity of the disease correlates with the NAA concentration in the brain, which was significantly lower in Nat8L $\mathrm{L}^{+/-} / \mathrm{Aspa}^{\text {nur7/nur7 }}$ mice. This, together with the apparently normal phenotype of Nat8 $\mathrm{L}^{-/-} / \mathrm{Aspa}^{\text {nur7/nur7 }}$ mice, is consistent with the hypothesis that the osmotic stress of accumulating NAA is the main factor responsible for disease progression in $\mathrm{CD}$ (Baslow et al., 2013). Moreover, it provides strong support for the hypothesis that the inhibition of NAA synthase is a promising therapeutic option for CD. Importantly, however, the therapeutic window may be narrow, because severe reduction of NAA may result in premature death not related to myelin pathology. Crossing the herein described conditional (floxed) Nat8L-deficient mice with inducible Cre-transgenic mice can serve as a model to further prove the feasibility of such a substrate reduction therapy.

\section{References}

Ahmed SS, Li H, Cao C, Sikoglu EM, Denninger AR, Su Q, Eaton S, Liso Navarro AA, Xie J, Szucs S, Zhang H, Moore C, Kirschner DA, Seyfried TN, Flotte TR, Matalon R, Gao G (2013) A single intravenous rAAV injection as late as P20 achieves efficacious and sustained CNS Gene therapy in Canavan mice. Mol Ther 21:2136-2147. CrossRef Medline

Arun P, Madhavarao CN, Moffett JR, Hamilton K, Grunberg NE, Ariyannur PS, Gahl WA, Anikster Y, Mog S, Hallows WC, Denu JM, Namboodiri AM (2010) Metabolic acetate therapy improves phenotype in the tremor rat model of Canavan disease. J Inherit Metab Dis 33:195-210. CrossRef Medline

Baslow MH (2003) N-acetylaspartate in the vertebrate brain: metabolism and function. Neurochem Res 28:941-953. CrossRef Medline

Baslow MH, Guilfoyle DN (2013) Canavan disease, a rare early-onset human spongiform leukodystrophy: insights into its genesis and possible clinical interventions. Biochimie 95:946-956. CrossRef Medline

Becker I, Wang-Eckhardt L, Yaghootfam A, Gieselmann V, Eckhardt M (2008) Differential expression of (dihydro)ceramide synthases in mouse brain: oligodendrocyte-specific expression of CerS2/Lass2. Histochem Cell Biol 129:233-241. CrossRef Medline

Becker I, Lodder J, Gieselmann V, Eckhardt M (2010) Molecular characterization of N-acetylaspartylglutamate synthetase. J Biol Chem 285:2915629164. CrossRef Medline

Bjartmar C, Battistuta J, Terada N, Dupree E, Trapp BD (2002) $\mathrm{N}$-acetylaspartate is an axon-specific marker of mature white matter in vivo: a biochemical and immunohistochemical study on the rat optic nerve. Ann Neurol 51:51-58. CrossRef Medline

Burlina AP, Corazza A, Ferrari V, Erhard P, Künnecke B, Seelig J, Burlina AB (1994) Detection of increased urinary N-acetylaspartylglutamate in Canavan disease. Eur J Pediatr 153:538-539. CrossRef Medline

Canavan MM (1931) Schilder's encephalitis periaxialis diffusa: Report of a case in a child aged sixteen and one-half months. Archives of Neurology \& Psychiatry 25:299-308. CrossRef

Chakraborty G, Mekala P, Yahya D, Wu G, Ledeen RW (2001) Intraneuronal $\mathrm{N}$-acetylaspartate supplies acetyl groups for myelin lipid synthesis: evidence for myelin-associated aspartoacylase. J Neurochem 78:736-745. CrossRef Medline

Collard F, Stroobant V, Lamosa P, Kapanda CN, Lambert DM, Muccioli GG, Poupaert JH, Opperdoes F, Van Schaftingen E (2010) Molecular identification of $\mathrm{N}$-acetylaspartylglutamate synthase and beta-citrylglutamate synthase. J Biol Chem 285:29826-29833. CrossRef Medline

D’Adamo AF Jr, Yatsu FM (1966) Acetate metabolism in the nervous system: N-acetyl-L-aspartic acid and the biosynthesis of brain lipids. J Neurochem 13:961-965. CrossRef Medline

Edwards K, Griffiths D, Morgan J, Pitman R, von Ruhland C (2009) Can the choice of intermediate solvent or resin affect glomerular basement membrane thickness? Nephrol Dial Transplant 24:400-403. Medline

Guo F, Bannerman P, Mills Ko E, Miers L, Xu J, Burns T, Li S, Freeman E, McDonough JA, Pleasure D (2015) Ablating N-acetylaspartate prevents 
leukodystrophy in a Canavan disease model. Ann Neurol 77:884-888. CrossRef Medline

Hogan B, Beddington R, Constantini F, Lacy E (1994) Manipulating the mouse embryo: a laboratory manual, Ed 2. New York: Cold Spring Harbor Laboratory.

Hoshino H, Kubota M (2014) Canavan disease: clinical features and recent advances in research. Pediatr Int 56:477-483. CrossRef Medline

Klugmann M, Leichtlein CB, Symes CW, Serikawa T, Young D, During MJ (2005) Restoration of aspartoacylase activity in CNS neurons does not ameliorate motor deficits and demyelination in a model of Canavan disease. Mol Ther 11:745-753. CrossRef Medline

Ledeen RW, Wang J, Wu G, Lu ZH, Chakraborty G, Meyenhofer M, Tyring SK, Matalon R (2006) Physiological role of N-acetylaspartate: contribution to myelinogenesis. Adv Exp Med Biol 576:131-143; discussion 361363. CrossRef Medline

Lodder-Gadaczek J, Becker I, Gieselmann V, Wang-Eckhardt L, Eckhardt M (2011) N-acetylaspartylglutamate synthetase II synthesizes $\mathrm{N}$-acetylaspartylglutamylglutamate. J Biol Chem 286:16693-16706. CrossRef Medline

Madhavarao CN, Arun P, Moffett JR, Szucs S, Surendran S, Matalon R, Garbern J, Hristova D, Johnson A, Jiang W, Namboodiri MA (2005) Defective $\mathrm{N}$-acetylaspartate catabolism reduces brain acetate levels and myelin lipid synthesis in Canavan's disease. Proc Natl Acad Sci U S A 102:52215226. CrossRef Medline

Magin TM, McWhir J, Melton DW (1992) A new mouse embryonic stem cell line with good germ line contribution and gene targeting frequency. Nucleic Acids Res 20:3795-3796. CrossRef Medline

Martin E, Capone A, Schneider J, Hennig J, Thiel T (2001) Absence of $\mathrm{N}$-acetylaspartate in the human brain: impact on neurospectroscopy? Ann Neurol 49:518-521. Medline

Matalon R, Michals K, Sebesta D, Deanching M, Gashkoff P, Casanova J (1988) Aspartoacylase deficiency and N-acetylaspartic aciduria in patients with Canavan disease. Am J Med Genet 29:463-471. CrossRef Medline

Matalon R, Rady PL, Platt KA, Skinner HB, Quast MJ, Campbell GA, Matalon K, Ceci JD, Tyring SK, Nehls M, Surendran S, Wei J, Ezell EL, Szucs S (2000) Knock-out mouse for Canavan disease: a model for gene transfer to the central nervous system. J Gene Med 2:165-175. Medline

Matalon R, Michals-Matalon K, Surendran S, Tyring SK (2006) Canavan disease: studies on the knockout mouse. Adv Exp Med Biol 576:77-93; discussion 361-363. CrossRef Medline

Mersmann N, Tkachev D, Jelinek R, Röth PT, Möbius W, Ruhwedel T, Rühle S, Weber-Fahr W, Sartorius A, Klugmann M (2011) AspartoacylaselacZ knockin mice: an engineered model of Canavan disease. PLoS One 6:e20336. CrossRef Medline
Moffett JR, Ross B, Arun P, Madhavarao CN, Namboodiri AM (2007) $\mathrm{N}$-Acetylaspartate in the CNS: from neurodiagnostics to neurobiology. Prog Neurobiol 81:89-131. CrossRef Medline

Moffett JR, Arun P, Ariyannur PS, Garbern JY, Jacobowitz DM, Namboodiri AM (2011) Extensive aspartoacylase expression in the rat central nervous system. Glia 59:1414-1434. CrossRef Medline

Namboodiri AM, Moffett JR, Arun P, Mathew R, Namboodiri S, Potti A, Hershfield J, Kirmani B, Jacobowitz DM, Madhavarao CN (2006) Defective myelin lipid synthesis as a pathogenic mechanism of Canavan disease. Adv Exp Med Biol 576:145-163. CrossRef Medline

Pessentheiner AR, Pelzmann HJ, Walenta E, Schweiger M, Groschner LN, Graier WF, Kolb D, Uno K, Miyazaki T, Nitta A, Rieder D, Prokesch A, Bogner-Strauss JG (2013) NAT8L (N-acetyltransferase 8-like) accelerates lipid turnover and increases energy expenditure in brown adipocytes. J Biol Chem 288:36040-36051. CrossRef Medline

Surendran S, Ezell EL, Quast MJ, Wei J, Tyring SK, Michals-Matalon K, Matalon R (2004) Aspartoacylase deficiency does not affect $\mathrm{N}$-acetylaspartylglutamate level or glutamate carboxypeptidase II activity in the knockout mouse brain. Brain Res 1016:268-271. CrossRef Medline

Surendran S, Campbell GA, Tyring SK, Matalon R (2005) Aspartoacylase gene knockout results in severe vacuolation in the white matter and gray matter of the spinal cord in the mouse. Neurobiol Dis 18:385-389. CrossRef Medline

Traka M, Wollmann RL, Cerda SR, Dugas J, Barres BA, Popko B (2008) Nur7 is a nonsense mutation in the mouse aspartoacylase gene that causes spongy degeneration of the CNS. J Neurosci 28:11537-11549. Medline

Truckenmiller ME, Namboodiri MA, Brownstein MJ, Neale JH (1985) $\mathrm{N}$-Acetylation of L-aspartate in the nervous system: differential distribution of a specific enzyme. J Neurochem 45:1658-1662. CrossRef Medline

Wang J, Leone P, Wu G, Francis JS, Li H, Jain MR, Serikawa T, Ledeen RW (2009) Myelin lipid abnormalities in the aspartoacylase-deficient tremor rat. Neurochem Res 34:138-148. CrossRef Medline

Wiame E, Tyteca D, Pierrot N, Collard F, Amyere M, Noel G, Desmedt J, Nassogne MC, Vikkula M, Octave JN, Vincent MF, Courtoy PJ, Boltshauser E, van Schaftingen E (2009) Molecular identification of aspartate $\mathrm{N}$-acetyltransferase and its mutation in hypoacetylaspartia. Biochem J 425:127-136. Medline

Yaghootfam A, Gieselmann V, Eckhardt M (2005) Delay of myelin formation in arylsulphatase A-deficient mice. Eur J Neurosci 21:711-720. CrossRef Medline

Zöller I, Meixner M, Hartmann D, Büssow H, Meyer R, Gieselmann V, Eckhardt M (2008) Absence of 2-hydroxylated sphingolipids is compatible with normal neural development but causes late-onset axon and myelin sheath degeneration. J Neurosci 28:9741-9754. CrossRef Medline 